\title{
MISPLACED CONSTITUTIONAL RIGHTS
}

\author{
BRANDON L. GARRETT*
}

\begin{abstract}
Constitutional rulings risk an unnoticed type of mission creep: misplacement through adoption in settings that they were not designed to regulate. This Article describes how in a set of important areas-and sometimes despite the Supreme Court's explicit cautionary language-constitutional rules have taken hold outside of the settings that they were primarily designed to regulate, providing unanticipated additions to rules and practice. Constitutional rights and standards are often context limited to particular government actors, procedural settings, or remedies. Based on the text of the Constitution or precedent, some rights apply only during civil cases, while others apply only during criminal cases; some regulate executive actors, while others exclusively relate to judicial officers. Misplacement can occur if, for example, a right that regulates evidence at criminal trials is extended, without support, to regulate executive officers. This type of misplacement has occurred in areas including eyewitness evidence, civil punitive damages, and the Miranda warnings. In addition, executive actors, ranging from administrative agencies to local police, may incorporate into their decision-making constitutional rules not intended to provide guidance in such settings. In doing so, actors may overprotect or, far more troubling, underprotect constitutional rights in unintended ways. It can be quite valuable to borrow from constitutional law, including to safeguard rights and harmonize nonconstitutional law with constitutional standards. However, doing so requires far more careful decision-making beginning with clearer judicial guidance on where and to whom constitutional rights should attach. The problem of misplaced constitutional rights should be addressed far more carefully by judges and government actors.
\end{abstract}

\footnotetext{
$\dagger$ (C) 2020 Brandon L. Garrett.

* L. Neil Williams, Jr. Professor of Law and Director of the Wilson Center for Science and Justice, Duke University School of Law. Many thanks to Kerry Abrams, Eric Berger, Josh Bowers, Anne Coughlin, Kate Elengold, Daniel Epps, Kim Ferzan, Barry Friedman, Lisa Griffin, Carissa Hessick, David Jaros, Bill Marshall, John Monahan, Caleb Nelson, Leigh Osofsky, Fred Schauer, Ted Shaw, Bobbie Spellman, Seth Stoughton; participants at workshops at the University of North Carolina School of Law, Duke University School of Law, and University of Virginia School of Law for their invaluable comments on early drafts; and Andres Paciuc and Brian Rho for their excellent research assistance.
} 


\section{CONTENTS}

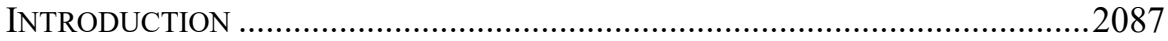

I. PLACEMENT OF CONSTITUTIONAL RightS.......................................2091

A. Rights Attached to Government Actors .....................................2091

B. Rights Attached to Procedural Settings .......................................2094

C. Rights Attached to Remedies ....................................................2097

D. Interpretation Drawing on Multiple Sources ............................2098

II. MisPlaCED CONSTITUTIONAL INFLUENCE ON COURTS ......................2098

A. Eyewitness Identifications: Instructing Jurors on

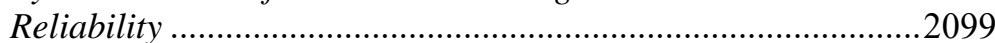

B. Punitive Damages: Instructing the Jury on Appellate

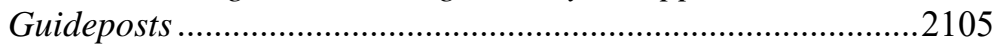

C. Miranda: Instructing the Jury on Prophylactic Rights ..............2108

D. Civil Causation and Criminal Materiality Standards.................2112

III. MisPlaCED CONSTITUTIONAL INFLUENCE ON EXECUTIVES...............2113

A. Fourth Amendment Rulings and Police Use-of-Force Policies 2113

B. Miranda and Police Policy ....................................................2114

C. Eyewitness Identification Procedure …….................................2118

IV. AVOIDING MisPlaced CONSTITUTIONAL LAW ...............................2121

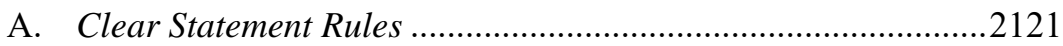

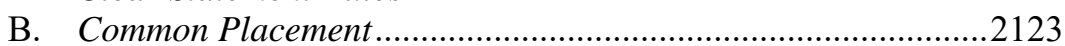

C. Rethinking Jury Instructions......................................................2124

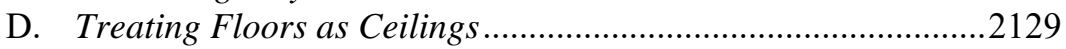

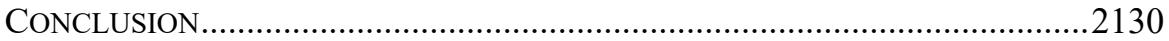




\section{INTRODUCTION}

Constitutional rulings are not just declared by the Supreme Court and then applied in a rote fashion by lower courts. Constitutional rights must be interpreted and implemented by varied government actors, and they may influence various branches of government and public opinion. When constitutional rights are intended to regulate government actors, complex questions may arise with regard to the implementation of those rights in areas including criminal procedure, all the way from the initial investigations to assertions of rights as defenses in criminal cases; civil damages awards; and actions seeking injunctive relief against government agencies or officials. ${ }^{1}$ In this Article, I develop a set of shadow consequences in which actors use constitutional rights intended to inform rules and practice in one setting in a different and unauthorized setting instead. Those constitutional standards are thus misplaced.

Constitutional text or interpretation can limit the reach of a constitutional right to a particular actor, procedural context, or remedy. ${ }^{2}$ Some rights govern federal and not state actors. ${ }^{3}$ Some rights provide a remedy in civil cases seeking damages but not during criminal trials, or vice versa. ${ }^{4}$ If an executive, judicial, or legislative actor applies a constitutional right or standard to (1) the wrong government actor, (2) the wrong procedural setting, or (3) the wrong remedy, constitutional law can be - as I call it in this Article for lack of an existing term for the phenomenon - misplaced. To be sure, in many areas, government actors can choose to provide greater protection than the Constitution demands; the Constitution typically provides a floor, not a ceiling. ${ }^{5}$ In still other areas, the

\footnotetext{
1 This Article builds on an earlier piece that develops what rules should govern the intersection of constitutional and evidence law. See generally Brandon L. Garrett, Constitutional Law and the Law of Evidence, 101 CoRNELL L. REv. 57 (2015). There, I argue that the intersection is undertheorized and that courts require clearer rules for resolving conflicts. Id. at 59. I further argue that sound protection of constitutional interests may be far more compatible with evidence law rules than often supposed but only if there is careful engagement with the potential impact of the constitutional rule on evidence practice. Id. at 87-98. For an exploration of the "creep," or the influence of constitutional amendment provisions on interpretation of substantive rights - an interesting but different, structural question—see generally Jonathan L. Marshfield, Amendment Creep, 115 MicH. L. REV. 215 (2016).

${ }^{2}$ For a description of how constitutional rights can be developed through decision rules that spell out obligations for particular government actors, see generally, for example, Mitchell N. Berman, Constitutional Decision Rules, 90 VA. L. REV. 1 (2004).

${ }^{3}$ For examples, see infra Section I.A.

${ }^{4}$ For examples, see infra Section I.B.

5 See, e.g., William J. Brennan, Jr., State Constitutions and the Protection of Individual Rights, 90 HARV. L. REV. 489, 495, 503 (1977) ("[M]ore and more state courts are construing state constitutional counterparts of provisions of the Bill of Rights as guaranteeing citizens of their states even more protection than the federal provisions ...."); William F. Swindler, Minimum Standards of Constitutional Justice: Federal Floor and State Ceiling, 49 Mo. L. REV. 1, 7-11 (1984) (discussing Missouri's and Virginia's changes to their state constitutions
} 
Supreme Court may not have clearly articulated to which actors or procedural settings a right may be applicable or what remedies may be available for violations of the right. In such instances there is no misplacement, as described here, if such placement options remain undefined or open.

When an application of a constitutional right does occur in clear contravention of text or precedent, then such misplacement can under- and overprotect constitutional rights in important ways that have not been adequately understood. One example of a misplaced constitutional standard — an unintended use of a constitutional rule in an evidentiary context - occurs with the Miranda v. Arizona ${ }^{6}$ requirement that police provide a suspect the well-known set of admonitions before proceeding with a custodial interrogation. ${ }^{7}$ Those warnings, which now stand on a firmer constitutional foundation, ${ }^{8}$ were never designed to guide jurors in assessing the value of confession evidence at a criminal trial but rather were designed to deter abusive questioning tactics. ${ }^{9}$ And yet, as I describe in this Article, some state courts include in their standard form jury instructions a statement that jurors should consider whether Miranda warnings were given; 10 if Miranda was violated, then the evidence should not come in at trial. This jury instruction does not serve a protective role. Instead, it may underprotect the right by suggesting to jurors that, by having waived Miranda rights, a defendant's confession might be per se voluntary.

A similar example can be found regarding the Supreme Court's due process decision in Manson v. Brathwaite, ${ }^{11}$ which requires that a judge suppress unduly suggestive and unreliable eyewitness evidence. ${ }^{12}$ The rule was designed to

in light of federal constitutional interpretations).

6384 U.S. 436 (1966).

${ }^{7}$ Id. at 478-79 ("[W]hen an individual is taken into custody or otherwise deprived of his freedom by the authorities in any significant way and is subjected to questioning, ... [h] e must be warned prior to any questioning that he has the right to remain silent, that anything he says can be used against him in a court of law, that he has the right to the presence of an attorney, and that if he cannot afford an attorney one will be appointed for him prior to any questioning if he so desires.").

${ }^{8}$ Dickerson v. United States, 530 U.S. 428, 433 (2000) (affirming constitutional nature of Miranda ruling).

9 See Miranda, 384 U.S. at 445-58 (describing nature of interrogation tactics used by law enforcement and stating that " $[\mathrm{u}]$ nless a proper limitation upon custodial interrogation is achieved - such as these decisions will advance - there can be no assurance that practices of this nature will be eradicated in the foreseeable future").

10 See infra Section I.C. For a larger overview of state law standards in the area and how state courts have moved away from the constitutional floor, see Thomas D. Albright \& Brandon L. Garrett, The Law and Science of Eyewitness Evidence 70 (Aug. 3, 2020) (unpublished manuscript), https://papers.ssrn.com/sol3/papers.cfm?abstract_id=3675055 [https://perma.cc/23AB-XLUC].

11432 U.S. 98 (1977).

12 Id. at 114. 
render some identification evidence inadmissible, ${ }^{13}$ not to instruct a jury on how to weigh admissible eyewitness evidence. Yet, as I will describe, many state courts that provide instructions regarding eyewitness evidence have incorporated the Manson due process test into their model jury instructions. ${ }^{14}$ In important ways, these jury instructions may mislead jurors regarding the factors that make an eyewitness identification more or less reliable. This conclusion is informed by a large body of scientific research conducted in the decades since the Manson ruling. ${ }^{15}$ Not only should the constitutional standard not be used to advise jurors - it was never intended to be used in the courtroom in that fashion - but this use of the constitutional standard is also increasingly out of date. ${ }^{16}$

In a set of important and unrelated areas, and sometimes despite the Supreme Court's cautionary language, constitutional rules have taken hold outside of the settings that they were primarily designed to regulate, providing unanticipated additions to evidence rules and practice and more. Perhaps most troubling are the judicial decisions that profess not to alter other bodies of law but that have had that very effect. Rulings by the Court that were designed to elaborate the underlying constitutional right have done more; they have become part of the instructions given to a jury when weighing evidence in a case, have affected rules for admissibility of expert evidence, and have affected prosecution decisions, among other things. Extending constitutional rulings in this manner may actually erode rights. The Court may have carefully limited a right due to a concern with one remedy, such as an exclusion remedy at trial, without intending to foreclose another remedy, such as damages. Extending the limited form of the right may incorrectly close off all constitutional remedies altogether.

This problem of overextension of constitutional standards in new contexts could not be more prominent than in the area of police use of force. In highprofile cases, prosecutors decide whether to charge officers who use deadly force. ${ }^{17}$ In this context, civil constitutional standards have influenced prosecutors deciding whether to criminally charge police for using deadly force. To take one high-profile example, after former Cleveland police officer Timothy Loehmann shot and killed Tamir Rice, Timothy McGinty, the Cuyahoga County

${ }^{13}$ Id. ("We therefore conclude that reliability is the linchpin in determining the admissibility of identification testimony ...." (emphasis added)).

${ }^{14}$ See infra Section II.C.

15 See generally NAT'L Research COUnCIL, IdENTIFying the Culprit: Assessing EYEWITNESS IDENTIFICATION (2014) [hereinafter NRC REPORT] (summarizing research on eyewitness memory and criticizing Manson factors as not supported by that scientific research). I note that I served on the committee that produced that report.

16 See id. at 31-44 (summarizing developments in state statutes and judicial rulings). For a longer exploration of these changes, see Garrett \& Albright, supra note 10, at 30-61.

17 See Cynthia Lee, Reforming the Law on Police Use of Deadly Force: De-Escalation, Preseizure Conduct, and Imperfect Self-Defense, 2018 U. ILL. L. REV. 629, 633 ("This country has seen an increase in the number of officer-involved homicide prosecutions over the last several years."). 
prosecutor, concluded that his office should not present charges to a grand jury..$^{18}$ In presenting that conclusion to the public in a detailed report, McGinty cited Fourth Amendment rulings in civil, not criminal, cases. ${ }^{19}$ McGinty likely felt more secure citing to the authority of federal constitutional rulings despite making a decision whether to prosecute for a state law crime. While not legally wrong - it was an exercise of discretion and the prosecutor could have offered no justification at all - the use of a misplaced constitutional standard raises a different set of questions in that context. An important and unexplored question remains regarding the use of constitutional rights as justification.

Constitutional rights may go perversely underenforced through the extension of constitutional rulings to settings that they were not designed to apply to. ${ }^{20} \mathrm{I}$ argue that far more attention is owed to this problem of misplaced constitutional language in the murky and poorly understood operation of rules on the ground, at trials, and in still less clearly defined decision-making by executive officials. I suggest how courts can address the problem and how higher courts can intervene if lower courts do not. I also describe how executive actors and lawmakers can rethink constitutional floors and ceilings.

This set of problems is a subset of a larger problem of constitutional drift. Frederick Schauer has pointed out that, "[i]n interpretive arenas below the Supreme Court, one good quote [from the Supreme Court] is worth a hundred clever analyses of the holding." ${ }^{21}$ Casual phrases and entire doctrines can serve purposes entirely unintended from, and even at odds with, their origins. Supreme Court rulings and language from holdings can migrate into other rulings and contexts. In other contexts, the primary concern is with politically unaccountable judges rendering rulings that constrain democracy. ${ }^{22}$ What is novel about the problem of misplaced rights, however, is that while constitutional law can and often does inform government actors in productive ways that can safeguard against the erosion of constitutional rights in litigation, misplacement of constitutional standards can do the opposite. ${ }^{23}$ While we are familiar with

18 Timothy J. McGinty, Cuyahoga County Prosecutor's Report on the November 22, 2014 Shooting Death of TAmir Rice 70 (2015) [hereinafter Cuyahoga Report], http://prosecutor.cuyahogacounty.us/pdf_prosecutor/en-US/Rice\%20Case\%20Report \%20FINAL\%20FINAL\%2012-28a.pdf [https://perma.cc/3Y5V-HHAR].

${ }^{19}$ Id. at 39, 70 (discussing Fourth Amendment case law concerning whether officers' actions were reasonable and whether officers should receive qualified immunity).

20 See Richard H. Fallon, Jr., Foreword: Implementing the Constitution, 111 HARV. L. REv. 54, 149-52 (1997) ("On the whole, the Court's selection of tests has produced doctrines that tend more to underprotect than to overprotect constitutional norms."); Kermit Roosevelt III, Constitutional Calcification: How the Law Becomes What the Court Does, 91 VA. L. REV. 1649, 1667-86 (2005); Lawrence Gene Sager, Fair Measure: The Legal Status of Underenforced Constitutional Norms, 91 HARV. L. REV. 1212, 1213-20 (1978).

${ }^{21}$ Frederick Schauer, Opinions as Rules, 53 U. CHI. L. Rev. 682, 683 (1986) (book review).

22 See Lawrence Gene Sager, Foreword: State Courts and the Strategic Space Between the Norms and Rules of Constitutional Law, 63 TEX. L. REV. 959, 959 (1985).

23 See generally, e.g., Garrett, supra note 1 (describing the consequences of constitutional law being imported into the evidentiary context). 
constitutional prophylactic rules aimed at protecting rights, there is scarce literature about the opposite: misplaced use of constitutional standards that can erode rights.

In this Article, I conclude that far more care is warranted where constitutional standards were not intended to create constitutional law. That lower courts, executive actors, and others may build on the constitutional floor and incorporate constitutional norms into their decision-making is unremarkable. That actors may instead adopt uses contrary to the substance of constitutional law, however, suggests that far more attention should be paid to how rights are administered in practice.

\section{Placement OF CONSTitutional Rights}

Constitutional rights, based on both the text of the Constitution and the development of standards to interpret those rights, may apply to particular government actors, stages of proceedings, or types of proceedings, and they may call for specific remedies. First, this Part describes how constitutional rights can sometimes apply to particular government actors: some to federal actors; some to state and local actors; and some primarily to executive, judicial, or legislative officers. Second, constitutional rights may apply to all or just portions of a proceeding — such as providing remedies pretrial versus during a trial—while other rights apply at any stage or are not determinate. Third, rights may provide only particular remedies based on text, interpretation, or the implementation of statutes. In each of the following Sections, I provide brief examples of how each of these three ways in which constitutional rights may be defined and placed relate to the problem of subsequent misplacement.

\section{A. Rights Attached to Government Actors}

Constitutional rights based on text or precedent do not always apply to all possible actors or remedies available against those actors. Often, the Supreme Court has held that a constitutional doctrine or standard provides a remedy for its violation only in a particular context. Sometimes, constitutional text makes clear to which government actor its strictures and resulting remedies are addressed. ${ }^{24}$ For example, not all constitutional rights apply to state as opposed to federal actors. ${ }^{25}$ Some constitutional rights, as a matter of text, apply to criminal procedure and not to civil actions. ${ }^{26}$ Some constitutional rights are exclusively directed at executive actors and not at judicial actors. ${ }^{27}$ Some are

\footnotetext{
${ }^{24}$ See, e.g., Henry P. Monaghan, Constitutional Adjudication: The Who and When, 82 YALE L.J. 1363, 1384 (1973) (discussing how mootness doctrine is aimed at federal judiciary in its entirety).

${ }^{25} I d$.

${ }^{26}$ See, e.g., U.S. CONST. amend. V ("No person ... shall be compelled in any criminal case to be a witness against himself ...." (emphasis added)).

27 See, e.g., Hamdi v. Rumsfeld, 542 U.S. 507, 516 (2004); United States v. Leon, 468 U.S. 897, 906 (1984) (holding that "unlawful search or seizure itself" violates the Fourth Amendment right against unreasonable searches and seizures and that judicial "use of fruits
} 
directed at Congress. ${ }^{28}$ Others still, such as the Thirteenth and Twenty-First Amendments, are arguably also directed at private actors..$^{29}$

Many rights, however, do not make clear which actors they are addressed to and anticipate a judicial role in their enforcement. For example, some rights, like those created by the Fourth Amendment, are directed first at executive actors with the expectation that judicial officers then enforce them in litigation. ${ }^{30}$ Other rights, like those created the Due Process Clauses, ${ }^{31}$ have extremely broad language capable of being applied in civil and criminal cases against both state and federal executive, legislative, and judicial officers. Sometimes, the Supreme Court has extended constitutional text to reach additional actors - for example, incorporating most provisions of the Bill of Rights as against states through the Due Process Clause of the Fourteenth Amendment. ${ }^{32}$ In so doing, the Court required states to adopt constitutional floors to minimally comply with the Constitution. However, the Court typically does not impose constitutional ceilings. That is, states are free to exceed the strictures of the Constitution and provide greater remedies and protections. Although the Court has sometimes restricted Congress's ability to impose greater strictures on states than the Constitution provides, ${ }^{33}$ state and local actors can exceed the Constitution to impose additional protections.

To be sure, even if a constitutional right clearly applies - based on text and precedent - to a government actor, there may be difficult questions about whether a plaintiff has standing to assert a constitutional right, depending on

of a past unlawful search or seizure 'work[s] no new Fourth Amendment wrong" (alteration in original) (quoting United States v. Calandra, 414 U.S. 338, 345 (1974))).

${ }^{28}$ For example, certain Article I provisions, such as the Commerce Clause, may be asserted as a jurisdictional defense in litigation. See U.S. CONST. art. I, $\S 8$, cl. 3. Other Article I provisions directly limit Congress's authority and can be asserted affirmatively or as a defense if violative legislation was enforced. See id. art. I, § 9, cl. 3 ("No Bill of Attainder or ex post facto Law shall be passed.").

29 See id. amend. XXI, § 2 ("The transportation or importation into any State, Territory, or possession of the United States for delivery or use therein of intoxicating liquors, in violation of the laws thereof, is hereby prohibited."); id. amend. XIII, § 1 ("Neither slavery nor involuntary servitude, except as a punishment for crime whereof the party shall have been duly convicted, shall exist within the United States, or any place subject to their jurisdiction.").

${ }^{30}$ Nicholas Quinn Rosenkranz, The Subjects of the Constitution, 62 STAN. L. REV. 1209, 1240 (2010) ("The Fourth Amendment is written in the passive voice, so it does not specify who may violate it. But text and structure strongly suggest that the Fourth Amendment is concerned with executive and judicial actions rather than legislative actions." (emphasis added)).

${ }^{31}$ U.S. CONST. amends. V, XIV, § 1.

32 See, e.g., Wolf v. Colorado, 338 U.S. 25, 33 (1949) (holding that the Fourth Amendment is applicable to states through Fourteenth Amendment's Due Process Clause).

33 See, e.g., City of Boerne v. Flores, 521 U.S. 507, 536 (1997) (holding that congressional expansion of First Amendment freedoms via Religious Freedom Restoration Act exceeded Congress's enforcement powers under the Fourteenth Amendment). 
their injury and the government actor being sued. ${ }^{34} \mathrm{~A}$ constitutional right might not be legally cognizable if asserted by a particular type of plaintiff given a lack of a sufficiently concrete injury. Furthermore, the Supreme Court has sometimes, for federalism reasons, restricted the claims available to plaintiffs and the remedies that courts can award against state and local actors for constitutional violations. ${ }^{35}$

An area in which some observers view the Court as having itself misplaced a right is the sovereign immunity doctrine. The Eleventh Amendment clearly applies, based on its text, to cases in which a citizen of one state sues another state. ${ }^{36}$ However, beginning in Hans v. Louisiana, ${ }^{37}$ and more recently in cases like Alden v. Maine, ${ }^{38}$ the Court has extended that rule of immunity to cases in which a citizen sues the state of the person's citizenship in both federal and state court-based not just on the text of the Eleventh Amendment but also on the Tenth Amendment, unwritten structural federalism principles, and principles of political accountability. ${ }^{39}$ The Court had already sharply limited the ability of Congress to abrogate that immunity in Seminole Tribe v. Florida. ${ }^{40}$ Thus, the Court extended the right to different actors being sued in different courts and ruled that Congress could not undo those extensions of the doctrine by statute. This area is arguably full of misplacement. ${ }^{41}$ However, in this Article, I focus not on whether the Supreme Court has correctly placed a right but whether lower courts, lawmakers, and executive actors follow the Court's rulings regarding placement of rights.

34 See, e.g., City of Los Angeles v. Lyons, 461 U.S. 95, 105 (1983) (finding that federal court lacked jurisdiction to issue injunctions against state actors when plaintiff's asserted injury was conjectural).

35 See, e.g., Rizzo v. Goode, 423 U.S. 362, $377-78$ (1976) (relying on "important considerations of federalism" in declining to recognize a "right to mandatory equitable relief in some form when those in supervisory positions do not institute steps to reduce the incidence of unconstitutional police misconduct").

${ }^{36}$ U.S. CONST. amend. XI ("The Judicial power of the United States shall not be construed to extend to any suit in law or equity, commenced or prosecuted against one of the United States by Citizens of another State, or by Citizens or Subjects of any Foreign State."); see also Seminole Tribe v. Florida, 517 U.S. 44, 54 (1996) ("[T]he text of the Amendment would appear to restrict only the Article III diversity jurisdiction of the federal courts . ...").

37134 U.S. 1 (1890).

38527 U.S. 706 (1999).

39 See id. at 712; Hans, 134 U.S. at 15-18.

40 Seminole Tribe, 517 U.S. at 47 ("We hold that notwithstanding Congress' clear intent to abrogate the States' sovereign immunity, the Indian Commerce Clause does not grant Congress that power, and therefore $\S 2710(\mathrm{~d})(7)$ cannot grant jurisdiction over a State that does not consent to be sued.").

41 As William Marshall and Jason Cowart have put it: "State immunity jurisprudence is not generally known for its great legal craftsmanship." William P. Marshall \& Jason S. Cowart, State Immunity, Political Accountability, and Alden v. Maine, 75 Notre DAME L. REV. 1069, 1088 (2000). 
A constitutional right can be misplaced if a suit is allowed against the wrong government actor. For example, a federal court cannot permit a suit against an individual prosecutor based on criminal procedure violations at a trial; the Supreme Court has found that such prosecutorial misconduct is protected by absolute immunity. ${ }^{42}$ The only avenues available to victims of such violations are a challenge to the conviction on appeal, a post-conviction challenge, or a civil suit against law enforcement. Conversely, states could misplace this constitutional rule by citing the absolute immunity defense in a federal suit against a prosecutor pursuant to a state regulation. In doing so, states would be wrong to cite to this rule to foreclose state remedies, which may build upon the constitutional floor. A state court citing to the federal doctrine of absolute immunity - a doctrine based on an interpretation of a federal statute ${ }^{43}$ - would be relying on a misplaced interpretation of a federal cause of action for constitutional litigation. If the state court cited to the federal doctrine purely as informative or as an example of a leading approach, that would not be problematic, although reasonable people could disagree whether federal law is informative on that point. However, if the state court cites to federal doctrine as authoritative, that would be an error.

In general, federal constitutional limitations do not apply to private actors under the state action doctrine. Nevertheless, good arguments exist that private institutions should adopt constitutional norms and protections, and statutes may require them to do so. In so doing, constitutional rights or norms are not necessarily misplaced.

\section{B. Rights Attached to Procedural Settings}

Constitutional rights can attach to particular procedural settings. Rights may apply to all or just portions of a proceeding - for example, by providing remedies pretrial or instead during a trial — while other rights apply at any stage or are indeterminate. Thus, jury trial rights based on text extend to trial proceedings but not to other types of nontrial hearings or investigations. The Sixth Amendment applies "[i]n all criminal prosecutions," 44 and therefore its provisions, such as the right to counsel, apply in criminal cases but not in administrative or other types of hearings. ${ }^{45}$ That text has been interpreted not to apply to all phases of a criminal investigation but rather only to "critical" stages at which substantial rights of the accused may be at stake. ${ }^{46}$ In contrast, other rights apply during police investigations, such as Fourth Amendment rights. ${ }^{47}$ The Supreme Court has also elaborated constitutional standards that govern

\footnotetext{
42 See, e.g., Connick v. Thompson, 563 U.S. 51, 54 (2011) (finding that prosecutor's office could not be held liable for failure to train prosecutors "based on a single Brady violation").

4342 U.S.C. $\S 1983$ (2018).

44 U.S. CONST. amend. VI.

45 Thus, the right to representation at civil commitment hearings is a due process right and not a Sixth Amendment right. See Vitek v. Jones, 445 U.S. 480, 494-97 (1980).

${ }^{46}$ Kirby v. Illinois, 406 U.S. 682, 690 (1972).

${ }^{47}$ U.S. CONST. amend. IV.
} 
criminal procedure at trials. For example, the Ex Post Facto Clause applies to criminal cases and not civil cases, as the Court has made clear. ${ }^{48}$

Yet sometimes the Supreme Court has interpreted the same amendment-and even the same clause of the same amendment - to have different civil and criminal applications. For example, Fourth Amendment protections against the unreasonable use of force may create civil remedies but do not impact criminal trials. ${ }^{49}$ Fourth Amendment search and seizure rules may create both civil remedies ${ }^{50}$ and exclusionary remedies during criminal trials, ${ }^{51}$ but the Court has held that they do not apply during grand jury proceedings. ${ }^{52}$ The Court has held that Fourth Amendment rights cannot be raised in federal post-conviction litigation, but they can be raised during trial or on appeal. ${ }^{53}$ The Court has also held that a range of constitutional criminal procedure rights that call into question the validity of a conviction can be raised in a civil case but only after a conviction has been reversed. ${ }^{54}$ Moreover, the Court has repeatedly stepped in to police these boundaries of rights guaranteed in civil, criminal, and postconviction litigation. ${ }^{55}$

Thus, constitutional rights may also apply during more than one stage, such as during both investigations and trials. An example of the Supreme Court extending a right to executive officers - specifically, at a preliminary stage-is the well-known prophylactic Miranda right, or what Henry Monaghan has called "constitutional common law." ${ }^{6}$ The Fifth Amendment right against selfincrimination is a trial right but has been interpreted to include a privilege that may be asserted during investigations. The goal of Miranda was to provide additional guidance to police officers who question individuals, sometimes unrepresented by counsel, before any court proceeding at which a person might assert Fifth Amendment privilege before a judge ${ }^{57}$ By "[r]equiring Miranda warnings before custodial interrogation," the Supreme Court has explained, it

48 Ky. Union Co. v. Kentucky, 219 U.S. 140, 153 (1911).

49 See, e.g., Graham v. Connor, 490 U.S. 386, 388-89 (1989).

50 See, e.g., Pierson v. Ray, 386 U.S. 547, 557 (1967).

51 Mapp v. Ohio, 367 U.S. 643, 660 (1961).

52 United States v. Calandra, 414 U.S. 338, 342, 354-55 (1974).

53 Stone v. Powell, 428 U.S. 465, 494-95 (1976) (denying habeas corpus relief to prisoners despite finding that evidence used to convict them was seized in violation of the Fourth Amendment because state process provided them the opportunity for "full and fair litigation" of Fourth Amendment claims).

54 See, e.g., Heck v. Humphrey, 512 U.S. 477, 486-87 (1994).

55 For a description of the Court's efforts to police boundaries between civil and postconviction litigation, see Brandon L. Garrett, Innocence, Harmless Error, and Federal Wrongful Conviction Law, 2005 Wis. L. REV. 35, 53-55.

${ }^{56}$ Henry P. Monaghan, Foreword: Constitutional Common Law, 89 HARV. L. REV. 1 (1975); accord Berman, supra note 2; David A. Strauss, The Ubiquity of Prophylactic Rules, 55 U. CHI. L. REV. 190 (1988).

57 Miranda v. Arizona, 384 U.S. 436, $441-42$ (1966) ("We granted certiorari in these cases ... to give concrete constitutional guidelines for law enforcement agencies and courts to follow."). 
sought to "provide[] 'practical reinforcement' for the Fifth Amendment right." 58 The rule applies to law enforcement and is aimed at reinforcing police compliance with the Fifth Amendment. The right is also to be enforced in court; after all, if police violate the requirement, then there are exclusionary consequences at a criminal trial. ${ }^{59}$ As such, the right first attaches at a preliminary stage, before police questioning begins, and can then be asserted in court.

These detailed specifications can result in misplaced constitutional rights if a court applies the standard to a stage of proceedings to which the text or precedent had not previously applied it. Thus, if a judicial or executive officer applies the Sixth Amendment right to a criminal jury trial to a purely administrative trial or applies the Sixth Amendment right to counsel in a criminal trial to a civil matter, such actions would go beyond the constitutional text and beyond precedent. While a state can choose to exceed the constitutional floor, it would be incorrect to cite to the Sixth Amendment as a binding source. Similarly, based on rulings like Heck v. Humphrey, ${ }^{60}$ it would be incorrect to allow a person to sue in federal court for civil damages to remedy an alleged violation of a criminal procedure right that implicates the validity of the conviction before the conviction itself has been reversed. ${ }^{61}$

Conversely, it would be misplaced to cite to federal constitutional law as regulating a stage during which federal courts themselves do not apply the right or provide a remedy. While that federal constitutional law may be informative, it also may not be if the federal rule was designed to regulate a different type of proceeding. For example, the scope of the right to counsel at a criminal trial might not be informative in a civil matter. As such, it would be misplaced to cite to the Heck rule to bar a civil case once a conviction has in fact been properly reversed, since the rule's rationale was to prevent an end run around criminal appeals and post-conviction litigation.

A counterexample illustrates how the Supreme Court is very much capable of addressing faulty repurposing of constitutional rights when an abuse catches the Justices' attention. In Crane v. Kentucky, ${ }^{62}$ the state court had refused to let the defendant introduce the circumstances of a confession at trial, including that the defendant, when interrogated, had made statements inconsistent with the crime scene evidence. ${ }^{63}$ The state court apparently reasoned that this effort to cast into question the credibility of the confession was not proper because, as the prosecutor contended, the judge had already ruled before trial that, as a "legal

\footnotetext{
${ }^{58}$ New York v. Quarles, 467 U.S. 649, 654 (1984) (quoting Michigan v. Tucker, 417 U.S. 433, 444 (1974)).

59 See Miranda, 384 U.S. at 478 (discussing admissibility of statements obtained through interrogation).

60512 U.S. 477 (1994).

${ }^{61} \mathrm{Id}$. at $487-88$.

62476 U.S. 683 (1986).

${ }^{63} \mathrm{Id}$. at $685-86$.
} 
matter," the confession was voluntary under the Constitution. ${ }^{64}$ The Court addressed the issue head-on, ruling that such a view of the role of a constitutional voluntariness analysis "is premised on a misconception about the role of confessions in a criminal trial." 65 As the Court stated, in "laying down" due process rules regulating the voluntariness of confessions, a judge's "pretrial voluntariness determination does not undercut the defendant's traditional prerogative to challenge the confession's reliability during the course of the trial." ${ }^{66}$ The exclusion of the evidence surrounding the circumstances of the confession itself "deprived petitioner of his fundamental constitutional right to a fair opportunity to present a defense." 67

\section{Rights Attached to Remedies}

Constitutional rights can provide remedies specific to the right, due to text or judicial interpretation of the right. ${ }^{68}$ Sometimes the Supreme Court develops a standard to apply during a particular stage of litigation. For example, while the Due Process Clause regulates civil and criminal proceedings, the Court has elaborated applications of the clause specific to criminal trials. ${ }^{69}$ In other situations, the Court has decided that a standard for a constitutional remedy in one area is useful in another. If so, there can be a convergence of common constitutional standards. ${ }^{70}$ Similar rules may be adopted across constitutional rights regarding qualified immunity, tailoring of injunctive remedies, and liability of local officers.

How can these specifications result in misplaced constitutional remedies? To provide one example, in the Miranda context it would be wrong to provide an exclusionary remedy in a civil trial for a non-Mirandized statement; Miranda is intended to provide a remedy against self-incrimination. A question raised was whether there is a right to civil damages, as opposed to solely criminal exclusionary remedies, if police violate Miranda. In Chavez v. Martinez, ${ }^{71}$ the Court held that the remedies are solely criminal exclusionary remedies, not civil ones. ${ }^{72}$ If a federal court provided a civil damages remedy for a Miranda

\footnotetext{
${ }^{64} I d$. at 686.

${ }^{65} \mathrm{Id}$. at 687.

${ }^{66} \mathrm{Id}$. at 688.

${ }^{67}$ Id. at 687.

68 See Paul Gewirtz, Remedies and Resistance, 92 YALE L.J. 585, 587 (1983); Daryl J. Levinson, Rights Essentialism and Remedial Equilibration, 99 COLUM. L. REV. 857, 857, 860 (1999).

${ }^{69}$ Mooney v. Holohan, 294 U.S. 103, 112 (1935) (stating that it does not satisfy due process requirements "if a State has contrived a conviction through the pretense of a trial which in truth is but used as a means of depriving a defendant of liberty through a deliberate deception of court and jury by the presentation of testimony known to be perjured").

70 See Thomas K.S. Fu, Against Doctrinal Convergence in Constitutional Remedies, 10 STAN. J. C.R. \& C.L. 293, 296 (2014).

71538 U.S. 760 (2003).

${ }^{72}$ Id. at $772-73$.
} 
violation prior to the Chavez ruling, perhaps it would not be misapplying the constitutional right; the question was not settled. However, following the Court's ruling in Chavez, such damages would be the wrong remedy for a violation.

\section{Interpretation Drawing on Multiple Sources}

A different type of citation to authority can occur when a court relies on multiple constitutional sources to support a general proposition or relies on law in one area to influence interpretation in another. These situations would not be misplacements in the way that I describe here, although there may be much to critique (or recommend) in drawing conclusions based on structure or text across provisions of the Constitution. As John Manning has described, sometimes a court cites to an area of law not as binding but as influential. ${ }^{73}$ For example, to cite to the Ex Post Facto Clause in support of a more general interpretive canon or principle of nonretroactivity applicable in civil cases may be an inappropriate leap. ${ }^{74}$ However, while the analogy made by drawing on a range of constitutional sources to support a canon of interpretation may be forced or inappropriate, it is not formal misplacement as I describe it here. The Court is formally drawing on multiple sources for constitutional authority and is not seeking to apply a constitutional right or standard to a new area without justifying its decision to do so.

\section{MisPLACED CONSTITUTIONAL INFLUENCE ON COURTS}

In a range of areas, constitutional rights have influenced courts in ways in which they were not intended to do so. For example, judicial actors have adopted constitutional floors in areas in which the rights were primarily intended to apply to executive actors: during the pretrial stage, during police questioning, and in providing a potential exclusionary remedy before trial. This has occurred in the context of the well-known Miranda warnings; some courts have misplaced the right as a component of jury instructions. In other contexts, judges have similarly misplaced pretrial rights in jury instructions at trial. These misplacements have occurred in the context of the central due process test for regulating eyewitness evidence, constitutional remedies such as qualified immunity law, and due process rules regarding punitive damages. These misplacements have also influenced jury instructions and, as a result, civil and criminal trials. One reason for these misplacements may simply be that trial judges and drafters of jury instructions look to authoritative pronouncements from the Supreme Court and to constitutional law when drafting instructions, hoping to avoid reversible errors. In doing so, jury instructions parrot constitutional language for

\footnotetext{
73 John F. Manning, Clear Statement Rules and the Constitution, 110 CoLUM. L. REV. 399, 432 (2010).

${ }^{74}$ Id. at 404, 435 (arguing that, because the Ex Post Facto Clause proscribes enactment of retroactive criminal penalties, the Founders specifically determined the ways in which and to what degree to limit the Clause and thus to "[a]bstract[] from that specific proscription to a background value of nonretroactivity... makes nonsense of [the] constitutionmaking process").
} 
evidentiary uses not anticipated by the opinions that defined those constitutional rights. As such, these instructions can then work against the Court's goal in creating the underlying constitutional right.

I focus in this Part on such examples of unintended and potentially perverse uses of constitutional rights at both the pretrial and trial stages. These uses include (1) jury instructions that eyewitness identifications should be evaluated using Supreme Court-derived "reliability" factors that not only do not correspond with reliability but were never intended to serve that function; (2) jury instructions affected by Supreme Court rulings on punitive damages originally designed to guide appellate review; (3) jury instructions suggesting that Miranda compliance somehow provides evidence of voluntariness, despite the fact that the Miranda rule was designed to protect against coercion in the interrogation room; and (4) the misuse of criminal appeal standards in civil rights litigation.

\section{A. Eyewitness Identifications: Instructing Jurors on Reliability}

The Supreme Court in Manson v. Brathwaite adopted an approach seeking to reconcile due process concerns with evidentiary concerns in the area of eyewitness identifications. ${ }^{75}$ The Court famously emphasized that "reliability is the linchpin in determining the admissibility of identification testimony." 76 The "reliability" factors as adopted by the Court ask that the judge examine: (1) the eyewitness's opportunity to view the criminal at the time of the crime, (2) the eyewitness's degree of attention, (3) the accuracy of the description that the eyewitness gave of the criminal, (4) the eyewitness's level of certainty at the time of the identification procedure, and (5) the length of time between the crime and the identification procedure. ${ }^{77}$ Scholars have criticized the test-and I among them-but that is not the focus here. ${ }^{78}$ The focus here is on the use that this test has been put to, wholly outside of the question of whether a trial judge should have admitted the eyewitness testimony.

That due process test solely regulates the preliminary question of whether to admit eyewitness testimony at trial, not how that trial should be conducted if the testimony was properly admitted. Having admitted such testimony, traditionally, judges provide the jury with brief instructions regarding eyewitness

\footnotetext{
75 Manson v. Brathwaite, 432 U.S. 98, 117 (1977).

${ }^{76} \mathrm{Id}$. at 114.

77 Id.

${ }^{78}$ For examples of the criticism of the Supreme Court's due process test in light of subsequent scientific research, see generally, for example, Suzannah B. Gambell, Comment, The Need to Revisit the Neil v. Biggers Factors: Suppressing Unreliable Eyewitness Identifications, 6 Wyo. L. REv. 189 (2006); Timothy P. O'Toole \& Giovanna Shay, Manson v. Brathwaite Revisited: Towards a New Rule of Decision for Due Process Challenges to Eyewitness Identification Procedures, 41 VAL. U. L. REV. 109 (2006); and Gary L. Wells \& Deah S. Quinlivan, Suggestive Eyewitness Identification Procedures and the Supreme Court's Reliability Test in Light of Eyewitness Science: 30 Years Later, 33 LAW \& Hum. BeHAV. 1 (2009).
} 
identifications. Such instructions typically remind the jury to consider the credibility of an eyewitness like that of any other witness or briefly instruct the jurors that any eyewitness identification is part of the prosecutor's burden of proof in a criminal case (although a few states in recent years have adopted more detailed jury instructions)..$^{79}$ The Supreme Court, in its ruling in Manson, did not state any intent to regulate the manner in which a jury would be instructed; the question that the Justices decided was whether and when a judge might exclude eyewitness identification evidence. ${ }^{80}$

That is why I was quite surprised to learn that, following the Supreme Court's decision in Manson, some state courts supplemented general jury instructions with respect to judging the credibility of witnesses by including in specific jury instructions on eyewitness evidence the "reliability" factors named by the Court. For example, in 1991, the Connecticut Supreme Court approved instructions in which the judge instructed the jury:

[W] hen deciding the question of identification it should ... consider the "totality of all the circumstances affecting identification," listing the following specific factors:

"the opportunity which the witness had to observe the person, the degree of certainty of the identification made in court, whether the witness knew or had seen the person before the identification, the circumstances and degree of certainty or uncertainty of any out of court identifications made ... the length of time available to make the observations of the perpetrator ... the lighting conditions at the time of the crime, any physical descriptions that the witness may have given to the police, the physical and emotional condition of the witness at the time of the incident and the witness' powers of observation ...."

Other states do the same. Having surveyed jury instructions in all fifty states and the District of Columbia, I found that eighteen states and the District of Columbia adopt some standalone instruction on the subject of eyewitness identification evidence that repeats some version of the factors from the Manson test. ${ }^{82}$ For example, the Illinois instruction emphasizes that the "new instruction

79 New Jersey courts used such instructions a decade before State v. Henderson, 27 A.3d 872, 928 (N.J. 2011). See, e.g., State v. Robinson, 754 A.2d 1153, 1157 (N.J. 2000) ("It is your function as jurors to determine what weight, if any, to give to this testimony. You must decide whether it is sufficiently reliable evidence upon which to conclude that this defendant is the person who committed the offenses charged.").

${ }^{80}$ Manson, 432 U.S. at 99.

81 State v. Tatum, 595 A.2d 322, 330 (Conn. 1991) (third and fourth alterations in original), overruled in part by State v. Dickson, 141 A.3d 810, 830 (Conn. 2016).

82 They are: Alaska, Arizona, California, Georgia, Illinois, Iowa, Maryland, Michigan, Minnesota, Ohio, Oklahoma, South Carolina, South Dakota, Tennessee, Utah, Vermont, West Virginia, Wisconsin, and the District of Columbia. See, e.g., Ill. Supreme Court Comm. ON

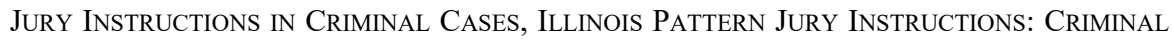
$\S 3.15$ (2017) [hereinafter ILL. CRIMINAL InSTRUCTIONS], https://courts.illinois.gov /CircuitCourt/CriminalJuryInstructions/CRIM _03.00.pdf [https://perma.cc/E57H-953J]; 
simply lists factors well-established by case law" and promptly cites, first in the list of authorities, to Manson. ${ }^{83}$ While a decade ago, the vast majority of states would have had instructions of that type, in recent years, many states have revised their eyewitness identification jury instruction, departing from the Manson model. Fifteen states - Connecticut, Florida, Georgia, Hawaii, Kansas, Maine, Massachusetts, Missouri, New Hampshire, New Jersey, New York, Ohio, Pennsylvania, Utah, and Virginia-have included some alterations, including modestly taking into account some of the more recent social science research on eyewitness memory. ${ }^{84}$ The New Jersey Supreme Court has recently

Mich. Supreme Court Comm. on Model Criminal Jury Instructions, Model Criminal JuRy InstruCtions 7-11 (2020) [hereinafter Mich. CRIMINAL Instructions], https://courts.michigan.gov/Courts/MichiganSupremeCourt/criminal-jury-

instructions/Documents/Criminal\%20Jury\%20Instructions.pdf [https://perma.cc/SN9AH9V4]. In some states, such as in South Carolina, the model instructions predate Manson and reflect the D.C. Circuit's recommended charges in United States v. Telfaire, 469 F.2d 552, 558-59 (D.C. Cir. 1972). See Ralph King Anderson, JR., South Carolina Requests to CHARgE - CRIMINAL § 6-1 (2d ed. 2012). Although in the past Alaska did not require any standard instructions and simply recommended the Telfaire approach, a recent ruling by the Alaska Supreme Court called for the drafting of revised jury instructions, which were then promulgated in 2020. Alaska CRiminal PATtERn JuRY InSTRUCTIONS COMM., AlasKa CRiminal PATtern JuRy InStRuction $§ 1.24$ (2020) (citing Young v. State, 374 P.3d 395, 427 (Alaska 2016)), https://public.courts.alaska.gov/web/crpji/docs/1.24.docx [https://perma.cc/4VZ9-MD6J] .

83 ILl. CRiminal InStRuctions, supra note 82, § 3.15 committee note, at 19.

${ }^{84}$ For example, the Florida instruction tells juries to consider whether the witness and offender are of different races or ethnic groups and does not include confidence as a factor. Fla. Supreme Court, Florida Standard Jury Instructions § 3.9(c) (2018), https://jury.flcourts.org/wp-content/uploads/Criminal/chapters/chapter3/p1c3s3.9.c.rtf [https://perma.cc/7FD6-MAH8]. The Georgia Supreme Court altered its instruction, which had adopted the Manson factors, to no longer emphasize confidence of the eyewitness. See Brodes v. State, 614 S.E.2d 766, 771 (Ga. 2005). The Kansas Supreme Court followed that same approach. See State v. Hunt, 69 P.3d 571, 575 (Kan. 2003), overruled in part by State v. Mitchell, 275 P.3d 905, 912-13 (Kan. 2012) (holding that "it is error to instruct the jury on the degree of certainty factor" and "discourag[ing] its future use"). The Supreme Court in Utah altered its instruction to focus on the effects of suggestion, as did the Connecticut Supreme Court. See State v. Marquez, 967 A.2d 56, 69-71 (Conn. 2009); State v. Ramirez, 817 P.2d 774, 780-81 (Utah 1991), abrogated by State v. Antonio Lujan, 459 P.3d 992, $995-$ 96 (Utah 2020) (overruling suggestion that admissibility of eyewitness identification testimony should be judged under a due process standard and holding that admissibility of this kind of evidence should be measured by the Utah rules of evidence; see also CRIMINAL Jury Instruction COMm., CONNECTICUt Judicial Branch CRiminal Jury Instructions $\S 2.6-4$ cmt. (2019) (citing, inter alia, State v. Dickson, 141 A.3d 810, 817 (Conn. 2016)), https://jud.ct.gov/JI/Criminal/Criminal.pdf [https://perma.cc/BB5L-78LJ]. New Jersey has now adopted a revised and detailed jury instruction that rejects the Manson factors as a model. See infra notes 176-79. Ohio revised its jury instruction in response to a statute requiring adoption of eyewitness identification procedures. See OHIO JuRy InSTRUCTIONS COMM., OHIO JURY InStRUCTIONS - CRIMINAL $§ 409.05$ (2012); see also OHIO REV. CODE ANN. § 2933.831 (West 2020). Virginia revised its jury instructions to include an eyewitness-specific 
and prominently outright rejected the Manson approach. ${ }^{85}$ The Massachusetts Supreme Judicial Council in 2015 "review[ed] the scholarly research, analyses by other courts, amici submissions," and a report by a Massachusetts Supreme Judicial Council Study Group on Eyewitness Identification that recommended that judges provide a revised set of jury instructions on eyewitness identification evidence. ${ }^{86}$ As a result, it included scientific principles in its eyewitness identification jury instruction. ${ }^{87}$ The Hawaiian courts have done the same in recent years. ${ }^{88}$

Sixteen of the other states do not specifically provide separate instructions on eyewitness evidence and instead generally instruct jurors that their task is to judge the credibility of witnesses, and one additional state has no criminal pattern instructions of any type..$^{89}$

Some state courts have also gone further and incorporated language from Supreme Court opinions on a related topic: the Sixth Amendment right to counsel at lineups. These courts have provided and approved jury instructions that inform the jury that there may be an "independent source" for an in-court identification, despite questions concerning earlier pretrial identification procedures. ${ }^{90}$ As I have written elsewhere, there is nothing "independent" about

instruction. VA. Model Jury Instructions Comm., Virginia Model JuRy InStructions CRIMINAL no. 2.800 (2019), http://www.courts.state.va.us/courts/circuit/resources/model jury_instructions_criminal.pdf [https://perma.cc/AFT3-RFZC]. In addition, certain states have adopted separate common-law tests concerning show-up identifications. See, e.g., Commonwealth v. Johnson, 650 N.E.2d 1257, 1261 (Mass. 1995); People v. Adams, 423 N.E.2d 379, 383-84 (N.Y. 1981); State v. Dubose, 699 N.W.2d 582, 599 (Wis. 2005), overruled by State v. Roberson, 935 N.W.2d 813, 816 (Wis. 2019) (overturning Dubose and "return[ing] to [the court's] past practice of following decisions of the United States Supreme Court in regard to criteria that are necessary to accord due process in eyewitness identifications"). North Carolina instructs witnesses regarding departures from statutorily mandated lineup practices. N.C. CONFERENCE OF SuPERIOR COURT JudGeS COMM. ON Pattern Instructions, North Carolina Pattern Jury Instructions for Criminal CASES $\S 105.65$ (2010), https://www.sog.unc.edu/sites/www.sog.unc.edu/files/pji-master /criminal/105.65.pdf [https://perma.cc/99ED-D3KU].

${ }^{85}$ See infra notes 176-79.

${ }^{86}$ Commonwealth v. Gomes, 22 N.E.3d 897, 905, 909-10 (Mass. 2015).

${ }^{87}$ Id. at 909-10.

${ }^{88}$ See, e.g., State v. Kaneaiakala, 450 P.3d 761, 774 (Haw. 2019) (“As a result of our holding in Cabinatan, the Jury Instructions Committee also promulgated Hawai'i Standard Instruction 3.19A regarding show-up identifications ....”); State v. Cabagbag, 277 P.3d 1027, 1035-39 (Haw. 2012) (holding that when eyewitness evidence is a central issue, a court must, at defendant's request, give a specific jury instruction about factors affecting reliability); see also HAw. Supreme COURT, HAw. PATtern JuRy InSTRUCTIONS, CRiminal no. 3.19 (2014), https://www.courts.state.hi.us/docs/legal_references/criminal_Jury _Instructions_oct_2014ada.pdf [https://perma.cc/A5YZ-LCQD].

89 Those states are: Alabama, Arkansas, Colorado, Idaho, Indiana, Kentucky, Louisiana, Mississippi, Montana, Nebraska, Nevada, New Mexico, North Dakota, Rhode Island, Texas, and Wyoming. Rhode Island has no pattern criminal jury instructions.

90 See, e.g., State v. Cannon, 713 P.2d 273, 281 (Ariz. 1985) (en banc) ("You are instructed 
the memory of an eyewitness in the courtroom. ${ }^{91}$ Regardless, the Sixth Amendment right to counsel at lineups was designed to ensure that a lawyer would be present at a postindictment lineup; it was not designed to inform the jury about the reliability or "independence" of the memory of an eyewitness who picks out the defendant in the courtroom.

Many federal courts adopt a still more dated approach, relying on instructions from the D.C. Circuit's 1972 decision in United States $v$. Telfaire, ${ }^{92}$ which was a kind of precursor to the Manson reliability test. Others have pattern instructions that refer to the Manson reliability test but modify the test in important respects. For example, the Third Circuit's eyewitness instruction states (although I note that a revision to these instructions has been recommended by a Third Circuit Task Force): ${ }^{93}$ "you should ask whether the witness was able to observe and had an adequate opportunity to observe the person who committed the crime charged." 94 However, the instructions then list factors such as "whether the witness was under stress while observing the person who committed the crime" and "whether the witness and the person committing the crime were of different races." 95 The instructions also cite to witness certainty and state "you should ask whether the witness is positive in the identification and whether the witness' testimony remained positive and unqualified after cross-examination." 96 Some federal courts also rely on the factors set out in Manson in deciding whether to give the jury expanded Telfaire jury instructions on eyewitness identification evidence. ${ }^{97}$ Oddly enough, their

that you must be satisfied beyond a reasonable doubt that the in-Court identification was independant [sic] of the previous pre-trial identification or, if not derived from an independent source, you must find from other evidence in the case that the defendant is the guilty person beyond a reasonable doubt.").

91 See Brandon L. Garrett, Eyewitnesses and Exclusion, 65 VAND. L. REV. 449, 494 (2012).

92469 F.2d 552, 558-59 (D.C. Cir. 1972).

93 Press Release, Joel McHugh, U.S. Court of Appeals for the Third Circuit, Third Circuit Task Force on Eyewitness Identifications Releases Its Report and Best-Practice Recommendations (Jan. 27, 2020), https://www.ca3.uscourts.gov/sites/ca3/files/Eyewitness \%20ID\%20TF_\%20Press\%20Release\%202019\%20Report_012720.pdf [https://perma.cc/3Z49-FGNG].

94 Comm. on Model Criminal Jury Instructions Third Circuit, Model Criminal JURY INSTRUCTIONS $§ 4.15$ (2018), ca3.uscourts.gov/sites/ca3/files/2018\%20Chapter\%204 \%20revisions\%20final.pdf [https://perma.cc/4UTR-T4TY].

95 Id.

${ }^{96} \mathrm{Id}$.

97 See, e.g., United States v. Thoma, 713 F.2d 604, 607-08 (10th Cir. 1983); United States v. Masterson, 529 F.2d 30, 31-32 (9th Cir. 1976) (considering "corroborating evidence" in finding that lower court did not err in declining to "give special jury instructions proposed by [defendant] on eyewitness identification"); see also Telfaire, 469 F.2d at 558-59. Some federal courts follow that approach, providing district courts with discretion to not employ the instructions should they conclude that based on "strong reliability" - assessed using the Neil v. Biggers/Manson factors - no such instruction is necessary. United States v. Luis, 835 F.2d 37, 41 (2d Cir. 1987) (citing Neil v. Biggers, 409 U.S. 188, 199-200 (1972)). 
reasoning seems to be that the Manson test provides a "reliability" framework for deciding whether to offer additional instructions that convey somewhat different information to jurors. ${ }^{98}$ There is nothing about that test that is based on empirical research concerning reliability of eyewitness evidence; the Justices crafted the test by drawing from prior case law on admissibility.

In contrast, courts do not currently appear to rely on the Manson test when deciding whether to admit expert testimony on eyewitness evidence in a criminal case. The overwhelming trend in state and federal courts in recent years has been to permit judges to admit such expert evidence. ${ }^{99}$ However, in the past, some state courts did cite to the Manson test as a reason not to approve use of experts on eyewitness identifications, noting that if an identification was sufficiently "reliable" to admit, then no expert opinion was necessary. ${ }^{100}$

Such rulings provide another example of courts mistakenly treating a constitutional floor as a ceiling. Indeed, the Supreme Court justified not revisiting the Manson test in its 2012 ruling in Perry v. New Hampshire ${ }^{101}$ by noting that state evidence law can more directly address reliability concerns for both expert testimony and "[e]yewitness-specific jury instructions." 102 It is truly ironic that the Supreme Court failed to address reliability concerns because it treated the subject as a matter for state evidence law while some state courts have refused to address reliability concerns because they see the federal constitutional test as governing. Trial courts can rely on evidence law to supplement a constitutional test, and they should do so more often in recognition that a constitutional right may serve a narrower evidentiary purpose. Courts should not engage in rote repetition of language from a Supreme Court decision that concerned admissibility and included factors not designed to be an exclusive list - certainly not when instructing jurors when considering whether to admit the testimony of an expert or when considering admissibility as a matter of state evidence law. In several different settings, lower courts extended the Manson

\footnotetext{
98 Luis, 835 F.2d at 41-42.

99 Commonwealth v. Walker, 92 A.3d 766, 792 (Pa. 2014) (rejecting per se ban on use of eyewitness expert evidence and describing how forty-four states, the District of Columbia, and "all or nearly all federal circuits" - excluding only one - now permit expert testimony on eyewitness evidence).

100 See, e.g., State v. Outing, 3 A.3d 1, 21 (Conn. 2010) (finding eyewitness expert testimony at issue inadmissible and noting that "the proper use of this expert testimony calls into question the soundness of the test set forth by the United States Supreme Court in Neil v. Biggers," which includes reliability factors subsequently adopted in Manson). But see State v. Guilbert, 49 A.3d 705, 731 n.33 (Conn. 2012) (rejecting reasoning in Outing and noting that admissibility of expert testimony raises different issues than admissibility of eyewitness evidence itself).

101565 U.S. 228 (2012).

102 Id. at 246 (noting existence of state-law "safeguards" in some states, including opportunity for defendant to present expert testimony on hazards of eyewitness identification evidence and availability of "[e]yewitness-specific jury instructions, which many ... state courts have adopted, [and which] likewise warn the jury to take care in appraising identification evidence" (footnote omitted)).
} 
test in unintended ways to limit remedies for potentially unreliable eyewitness evidence in criminal cases. ${ }^{103}$ Given how much we now know about reliability concerns with such evidence, the misplacement of due process precedent is extremely troubling.

\section{B. Punitive Damages: Instructing the Jury on Appellate Guideposts}

The Supreme Court's due process regulation of punitive damages formally applies posttrial to require that unconstitutionally excessive verdicts be reduced. ${ }^{104} \mathrm{As}$ in the examples just discussed, however, the Court's due process test has taken hold during civil trials in a manner that may not have been intended by the Justices. Beginning with its earliest decisions regulating punitive damages under the Due Process Clause, the Court expressed great deference to state judges' instructions to jurors. In Pacific Mutual Life Insurance Co. v. Haslip, ${ }^{105}$ the Court approved instructions that dissenters called "scarcely better than no guidance at all." 106 The opinion focused on due process standards for postverdict review, including the use of guideposts to assess whether punitive damages awards are arbitrarily excessive. ${ }^{107}$ The Court certainly gave directions that suggest methods of keeping such verdicts within bounds, but it did not provide guidance on how to avoid prejudicing jurors when presenting them with evidence of conduct outside the jurisdiction. ${ }^{108}$ The Court's standards are chiefly designed to govern appeals; for example, the suggestion that a punitive damages verdict should be no more than a single-digit multiple of the compensatory damage award is a yardstick for appellate courts, not a calculator for the jurors to use. 109

To be sure, the Court's decisions in State Farm Mutual Automobile Insurance Co. v. Campbell ${ }^{110}$ and Philip Morris USA v. Williams ${ }^{111}$ do urge that jurors be instructed on not punishing defendants for out-of-state conduct or conduct harming nonparty victims. As the Court put it in Philip Morris: "[T]he Due Process Clause requires States to provide assurance that juries are not asking the wrong question ...."112 Such rulings were intended to affect trial deliberations.

103 See supra note 84 and accompanying text.

104 See Pac. Mut. Life Ins. Co. v. Haslip, 499 U.S. 1, 18-24 (1991).

105499 U.S. 1 (1991).

${ }^{106} \mathrm{Id}$. at 48 (O'Connor, J., dissenting).

107 See id. at 22 (majority opinion).

108 See id. at 24 (Scalia, J., concurring in the judgment) ("This jury-like verdict provides no guidance as to whether any other procedures are sufficiently 'reasonable,' and thus perpetuates the uncertainty that our grant of certiorari in this case was intended to resolve.").

109 State Farm Mut. Auto. Ins. Co. v. Campbell, 538 U.S. 408, 425 (2003).

110538 U.S. 408 (2003).

111549 U.S. 346 (2007).

112 Id. at 355. The State Farm ruling provided guidance that jurors should be instructed that out-of-state conduct should not be used as a basis for punitive damages. State Farm, 538 U.S. at 422. The Philip Morris ruling stated that it would be "standardless" and impermissible for a jury to "permit punishment for injuring a nonparty victim." Philip Morris, 549 U.S. at 
However, nothing in rulings concerning guideposts suggests that jurors be provided with them during deliberations.

Many states have long retained general and minimal instructions on the subject of punitive damages. Indeed, although some states have revised their instructions since State Farm to provide more detailed instructions on the subject, many others have not. ${ }^{113}$ Even some federal courts retain traditional punitive damages jury instructions. For example, the Ninth Circuit pattern instructions simply state: "If you find that punitive damages are appropriate, you must use reason in setting the amount." 114 The Ninth Circuit has noted that the due process inquiry "is markedly different from the jury's determination of a specific amount of punitive damages; its purpose is to aid in ascertaining the constitutional ceiling. Unlike the initial damage calculation, determining the constitutional ceiling on a punitive damage award is a question of law, properly reserved for the court." 115 The Ninth Circuit added that, "[a]lthough states are certainly free to incorporate the reasonable relationship concept into jury instructions, it is also constitutionally permissible... to delay the reasonable relationship inquiry until the judge's post-verdict review."116

In contrast, some states have taken the hint from the Supreme Court's decisions and adopted substantive due process yardsticks as at least a discretionary part of their instructions to the jury. In Illinois, for example, "[t]he amount of punitive damages must be reasonable [and in proportion to the actual

354; see also Anthony J. Franze \& Sheila B. Scheuerman, Instructing Juries on Punitive Damages: Due Process Revisited After State Farm, 6 U. PA. J. Const. L. 423, 498-524 (2004); Neil Vidmar \& Matthew W. Wolfe, Fairness Through Guidance: Jury Instruction on Punitive Damages After Philip Morris v. Williams, 2 Charleston L. Rev. 307, 315-20 (2008) (explaining gaps in jury instructions and proposing that instructions should be more detailed).

113 For an excellent in-depth analysis, see Franze \& Scheuerman, supra note 112, at 47086 (noting that ten states maintain minimal jury instructions, eight more states and the District of Columbia adding only consideration of defendant's wealth, and twenty-eight states providing multiple-factor instructions); and Vidmar \& Wolfe, supra note 112, at 316-18 (describing issues with jury instructions, including lack of detail and undefined terms). Some states retain largely traditional instructions with modest additions noting that punitive damages must be "proportionate" to the actual harm. See, e.g., COMM. ON PATTERN JURY INSTRUCTIONS, N.Y. PATTERN JURY INSTRUCTIONS-CIVIL § 2:278 (2019) (adding caveats regarding out-of-state conduct and injury to third parties in response to State Farm and Phillip Morris). Some states have enacted statutes capping punitive damages, providing for specific instructions, or a combination of the two. See, e.g., OKLA. STAT. ANN. tit. 23, § 9.1(B) (West 2020) (limiting punitive damage awards to greater of $\$ 100,000$ or amount of actual damages awarded).

114 Ninth Circuit Jury Instructions Comm., Manual of Model Civil Jury Instructions for the District COURTS OF the Ninth Circuit $\S 5.5$ (2020), http://www3.ce9.uscourts.gov/jury-instructions/sites/default/files/WPD/Civil_Instructions _2020_5.pdf [https://perma.cc/HRP3-RN22].

115 White v. Ford Motor Co., 500 F.3d 963, 974 (9th Cir. 2007).

${ }^{116}$ Id. (citation omitted). 
and potential harm suffered by the plaintiff]."117 "Whether the bracketed language concerning 'proportionality' should be included in the instruction should be decided on a case by case basis"; 118 it is neither mandated nor prohibited by State Farm or Illinois law.

Here, the array of responses by state and federal courts to the Supreme Court's decisions should not be surprising. The Court has been intervening in an area traditionally defined by common-law standards and, more recently, the subject of specific state legislation and jury instructions. The Court has not been clear whether its due process concerns extend to jury instructions, as opposed to appellate review, except on two discrete subjects - out-of-state conduct and harm to third parties. The Court has been understandably reluctant to craft an entire set of more detailed instructions in an area where jurors traditionally had broad discretion. Indeed, Justices remain unsure whether improved jury instructions will adequately constrain juries or whether a numerical constraint posttrial does the job better. For example, in Exxon Shipping Co. v. Baker, 119 Justice Souter, writing for the Court, noted that the Justices, having read examples of ill-defined state jury instructions on punitive damages, have become "skeptical that verbal formulations, superimposed on general jury instructions, are the best insurance against unpredictable outliers." 120 Justice Souter found "obvious" the similarity to the goals of the U.S. Sentencing Guidelines and the comparative merits of a "quantified approach." 121 To some, the comparison with experience under the Sentencing Guidelines would instead provide more of a cautionary tale for attempts to quantify punishment. Such a comparison begged the question why the Court is authorized to impose specific caps or ratios, which are "typically imposed by legislatures, not courts."122

The Supreme Court moved in two directions at once, both tightening postverdict limits on the amount of punitive damages and limiting the subjects about which the jury may be instructed. Regardless of whether the Court's approach is advisable, it increasingly touches on matters of policy and the specifics of the implementation of that policy. As a result, if the Court intends to continue to intervene in this area and fashion a highly specific due process mechanism for regulating punitive damages awards, the Court will have to engage with evidentiary issues in far more detail. ${ }^{123}$

117 Ill. Supreme Court Comm. On Jury InStructions in Civil CASES, Illinois PATtern JURY INSTRUCTIONS - CIVIL $\$ 35.01$ (2007) (second alteration in original), https://courts.illinois.gov/CircuitCourt/CivilJuryInstructions/35.00.pdf

[https://perma.cc/35NL-Q3DT].

118 Id.

119554 U.S. 471 (2008).

${ }^{120} \mathrm{Id}$. at 504.

${ }^{121} I d$. Justice Stevens dissented as to the "empirical judgments" expressed in that portion of the opinion. Id. at 516 (Stevens, J., concurring in part and dissenting in part).

${ }^{122} \mathrm{Id}$. at 520 (noting that majority could not point to any state court that imposed particular ratio).

${ }^{123}$ For one scholar's prediction that the Court may, for the time being, have 


\section{Miranda: Instructing the Jury on Prophylactic Rights}

The well-known Miranda warnings that inform a suspect of their Fifth Amendment rights prior to a custodial interrogation were not intended to provide rules of evidence to guide jurors in their understanding of how to evaluate a confession. ${ }^{124}$ Instead, "[r]equiring Miranda warnings before custodial interrogation," the Supreme Court has explained, "provides "practical reinforcement' for the Fifth Amendment right."125 Nevertheless, some prominent jurisdictions instruct jurors on compliance with Miranda. The New York pattern jury instructions state:

Initially, under our law, before a person in custody may be questioned by the police [or an assistant district attorney], that person first, must be advised of his/her rights; second, must understand those rights; and third, must voluntarily waive those rights and agree to speak to the police [or an assistant district attorney]. ....

Before you may consider as evidence a statement made by the defendant in response to questioning, you must find beyond a reasonable doubt that the defendant was advised of his/her rights, understood those rights, and voluntarily waived those rights and agreed to speak to the police [or an assistant district attorney]. If you do not make those findings, then you must disregard the statement and not consider it. ${ }^{126}$

Other major jurisdictions do the same. ${ }^{127}$ The New Jersey model charge asks "whether or not the statement was actually made by the defendant, and, if made, whether the statement or any portion of it is credible." 128 The New Jersey model charge then directs the courts to discuss the proof presented before the jury that relates to the defendant's Miranda rights or the voluntariness of their

"unceremoniously" ended this era of regulating punitive damages awards, see generally Jim Gash, The End of an Era: The Supreme Court (Finally) Butts Out of Punitive Damages for Good, 63 Fla. L. REV. 525 (2011).

124 See New York v. Quarles, 467 U.S. 649, 654 (1984).

125 Id. (quoting Michigan v. Tucker, 417 U.S. 433, 444 (1974)).

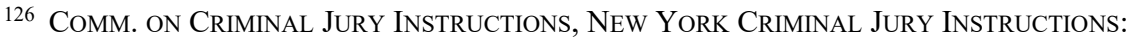
StATEMENTS (ADMisSions, CONFESSIONS) 6-7 (2019) [hereinafter NEW York CRIMINAL JURY INSTRUCTIONS] (first, second, and fourth alterations in original), http://www.nycourts.gov /judges/cji/1-General/CJI2d.Confession.pdf [https://perma.cc/4J9U-EUB5].

127 Texas has a general jury instruction that instructs the jury on the voluntariness of confessions, and at least one case assumes that it permits Miranda-related instructions. TEX. CODE Crim. Proc. ANN. art. $38.22 \S 7$ (West 2019) ("When the issue [of voluntariness of a statement made by an accused] is raised by the evidence, the trial judge shall appropriately instruct the jury, generally, on the law pertaining to such statement.”); Estrada v. State, 313 S.W.3d 274, 300 (Tex. Crim. App. 2010) (discussing whether defendant was entitled to "validity of Miranda waiver" instruction pursuant to Article $38.22 \S 7$ ).

128 N.J. Courts, Model Criminal Jury Charges: Statements of Defendant 1 (2010), https://njcourts.gov/attorneys/assets/criminalcharges/non2c024a.pdf [https://perma.cc/TBL9-MNKB]. 
statements. ${ }^{129}$ Other jurisdictions do not do so. For example, 18 U.S.C. § 3501(a) provides in part: "[T] he trial judge shall permit the jury to hear relevant evidence on the issue of voluntariness and shall instruct the jury to give such weight to the confession as the jury feels it deserves under all the circumstances." 130

Now, a judge or model instructions committee may simply be looking for factors relevant to an assessment of the voluntariness of a confession. Indeed, states may even desire to overprotect federal constitutional rights using their own evidence rules. Some states have rejected proposed jury instructions on the question whether the defendant had been given Miranda warnings; the concern seems to be that the defendant may be trying to relitigate whether Miranda was violated and to "comment on the weight of the evidence."131 In a Massachusetts case, it was the defendant who proposed, and the trial judge who accepted, a jury instruction explaining: "When the police take a person into custody, they give him certain warnings before any statements he makes in response to interrogation will be admissible in evidence. You have probably heard of them; they are called Miranda warnings." 132 Having lost the suppression hearing, the defendant may have hoped that the jury would still view the Mirandized statements as involuntary. One reason states have bent over backwards to instruct jurors on confessions, including on Miranda - even though it is not a rule designed to inform evaluation of the evidence - may be that the Supreme Court has strongly emphasized how important it is that a jury not consider involuntary confessions. The Court has emphasized that, for example, "[a] trial judge has a powerful tool at his disposal to protect the constitutional privilegethe jury instruction" and that when a defendant is silent, "[n]o judge can prevent jurors from speculating about why a defendant stands mute in the face of a criminal accusation, but a judge can, and must, if requested to do so, use the unique power of the jury instruction to reduce that speculation to a minimum."133

The use of Miranda in jury instructions, however, may not be more protective. Consider how the fact that a defendant did waive Miranda rights may only highlight that this was an informed and voluntary confession which followed the

${ }^{129} I d$.

13018 U.S.C. § 3501(a) (2018). Compare this Washington state instruction: "You may give such weight and credibility to any alleged out-of-court statements of the defendant as you see fit, taking into consideration the surrounding circumstances." Wa. STATE SUPREME COURT

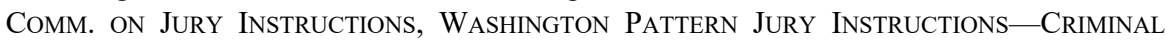
$\S 6.41$ (2016), https://govt.westlaw.com/wcrji/Document/Ief9e3bc7e10d11daade1ae871 d9b2cbe?viewType $=$ FullText\&originationContext $=$ documenttoc\&transitionType $=$ Category PageItem\&contextData=(sc.Default) [https://perma.cc/L6GZ-FNBR].

131 Mendoza v. State, 88 S.W.3d 236, 240 (Tex. Crim. App. 2002) (en banc) (ruling that trial court properly excluded proposed instructions reciting specific facts and evidence relating to voluntariness).

132 Commonwealth v. Stone, 877 N.E.2d 620, 627 (Mass. App. Ct. 2007) (outlining defendant's argument on appeal that trial judge's acceptance of defendant's proposed instruction created substantial risk of a miscarriage of justice because instruction suggested that defendant had been under arrest at time of statement).

133 Carter v. Kentucky, 450 U.S. 288, 303 (1981). 
waiver. If the defendant did invoke Fifth Amendment rights after receiving Miranda warnings, unless some exception applied (such as the use of such statements to impeach the defendant's testimony at trial), ${ }^{134}$ the confession would presumably not be before the jury. The instructions will therefore chiefly be used to highlight waivers of Miranda rights. The Supreme Court may not have intended a waiver of Miranda rights to serve as additional evidence that the confession that followed was in fact a voluntary one. But that is the use that Miranda may be put to (and it can be put to that use more commonly and informally when officers emphasize on the stand that they gave all of the required warnings to the suspect prior to securing a confession statement). While few criminal cases result in a trial, and the effect of Miranda during interrogations themselves is a separate and contested question, this account suggests that rules designed to serve one remedial purpose may be repurposed by lower courts.

Constitutional rulings are seen as relatively risk-free sources for inclusion in jury instructions. If a judge instructing a jury or a committee drafting model jury instructions is seeking language to underscore a point, what could be more authoritative than quoting the Supreme Court? This may not be an impermissible or completely unanticipated use of constitutional doctrine, but these examples do suggest that the process by which constitutional doctrine filters into practice in the trial courts remains underexamined.

That said, while holding that the defendant may present to the jury circumstances surrounding the voluntariness of a confession, the Supreme Court has not encouraged - much less required - judges to instruct jurors regarding the voluntariness of confessions. ${ }^{135}$ The Court in Lego v. Twomey ${ }^{136}$ emphasized instead that the voluntariness hearing before the judge, using a preponderance of the evidence standard of proof, is sufficient to determine the confession's admissibility, citing to "the normal rule that the admissibility of evidence is a question for the court rather than the jury." 137 Federal courts, following 18

134 Harris v. New York, 401 U.S. 222, 226 (1971) ("The shield provided by Miranda cannot be perverted into a license to use perjury by way of a defense, free from the risk of confrontation with prior inconsistent utterances."). Thus, when "Miranda-defective statements" are introduced for impeachment, California jury instructions appropriately require the trial judge to instruct the jury: "You may not consider it as proof that the statement is true or for any other purpose." JUDICIAL COUNCIL OF CAL. ADVISORY COMM. ON CRIMINAL JURY InSTRUCTIONS, CRIMINAL JURY INSTRUCTIONS $§ 356$ (2020), https://www.courts.ca.gov /partners/documents/calcrim_2020.pdf [https://perma.cc/K2QQ-AP8J].

135 See Lego v. Twomey, 404 U.S. 477, 486 (1972).

136404 U.S. 477 (1972).

137 Id. at 490; see also id. at 485-86, 486 n.14 (noting that defendant may present circumstances surrounding taking of confession to jury (citing 18 U.S.C. $§ 3501$ (a) (2018))). $\S 3501$ (a) provides:

In any criminal prosecution brought by the United States or by the District of Columbia, a confession, as defined in subsection (e) hereof, shall be admissible in evidence if it is voluntarily given. Before such confession is received in evidence, the trial judge shall, out of the presence of the jury, determine any issue as to voluntariness. If the trial judge 
U.S.C. § 3501(a), only minimally instruct the jury concerning a confession; the jurors are told to "give such weight to the confession as the jury feels it deserves under all the circumstances." 138 State courts need not adhere to that statute, and nothing in the Court's rulings forbids states from providing more detailed guidance concerning the manner in which to weigh confession evidence or postarrest statements. Few state courts, however, have departed from the bare minimum of no voluntariness instruction required by the Court. 139

determines that the confession was voluntarily made it shall be admitted in evidence and the trial judge shall permit the jury to hear relevant evidence on the issue of voluntariness and shall instruct the jury to give such weight to the confession as the jury feels it deserves under all the circumstances.

13818 U.S.C. § 3501(a); see also, e.g., COMM. ON FED. CRIMINAL JURY InSTRUCTIONS OF the Seventh Circuit, Pattern Criminal Jury Instructions of the Seventh Circuit, $\S 3.09$ (2019) http://www.ca7.uscourts.gov/pattern-jury-instructions/Pattern_Criminal_Jury _Instructions_2012ed_includes_2015-2019_changes.pdf [https://perma.cc/A4D6-LBU4] ("You must decide whether [the defendant; defendant [name]] actually made the statement and, if so, how much weight to give to the statement. In making these decisions, you should consider all of the evidence, including the defendant's personal characteristics and circumstances under which the statement may have been made." (alterations in original)); Ninth Circuit Jury instructions Comm., Manual of Model Criminal Jury $\begin{array}{llllll}\text { InSTRUCTIONS } & \S 4.1 \quad(2020) & \text { [hereinafter NinTH } & \text { Circuit } & \text { Manual }\end{array}$ http://www3.ce9.uscourts.gov/jury-instructions/node/355 [https://perma.cc/6TEG-L8HC] ("It is for you to decide (1) whether the defendant made the statement, and (2) if so, how much weight to give to it. In making those decisions, you should consider all the evidence about the statement, including the circumstances under which the defendant may have made it.").

139 See, e.g., Mich. CRIMINAL InSTRUCTIONS, supra note 82, § 4.1(3) ("If you find that the defendant did make the statement, you may give the statement whatever weight you think it deserves. In deciding this, you should think about how and when the statement was made, and about all the other evidence in the case. You may consider the statement in deciding the facts of the case [and in deciding if you believe the defendant's testimony in court]." (alteration in original)). Some states cite to Lego as a reason not to adopt more detailed instructions on voluntariness. See, e.g., NevadA Model Criminal JURY Instructions: CONFESSION/ADMISSION 22-23 (on file with the Boston University Law Review) ("Voluntariness is based on the totality of circumstances, no one factor being controlling. If you decide that a statement was made voluntarily, then you may consider it in determining the guilt or innocence of the defendant making the statement." (citing, inter alia, Lego, 404 U.S. 477)). Other states do provide expanded instructions regarding voluntariness. See, e.g., N.H. BAR ASS'N TASK ForCE ON CRIMINAL JURY INSTRUCTIONS DRAFTING COMM., CRIMINAL JURY InSTRUCTION ON CONFESSIONS OR ADMISSIONS 14 (Draft 2010) http://nhba.s3.amazonaws.com/wp-content/uploads/2018/03/14150801/CJI.pdf

[https://perma.cc/2DKW-4QXZ] ("The basic test is whether the police exerted such an influence over the defendant that [his] [her] will was overborne. In making this decision, you should consider all of the circumstances surrounding the defendant's statements, including the time and place the [confession] [admissions] occurred, the length of time the defendant was questioned, and the physical and mental condition of the defendant. You may also consider the age, education, experience, character and intelligence of the defendant to the extent that you have heard such evidence." (alterations in original)); NEW YORK CRIMINAL JURY INSTRUCTIONS, supra note 126, at 9. 
Now that many more state statutes require videotaping of interrogations, more states have added certain additional cautionary jury instructions should not follow a rule requiring recording of interrogations. ${ }^{140}$ Perhaps, after many decades of giving the traditional and minimal instructions endorsed by the Supreme Court in Lego, we may start to see more experimentation in the states. ${ }^{141}$ That Supreme Court rulings not intended to regulate police conduct may have stifled such experimentation, though, provides an important cautionary tale.

\section{Civil Causation and Criminal Materiality Standards}

A range of constitutional criminal procedure rights include a materiality standard designed to ensure that during appellate review - or, more typically, post-conviction review - a court does not grant relief unless the error had an adequate effect on the criminal verdict at trial. For example, the Brady $v$. Maryland ${ }^{142}$ rule contains that requirement; it is not enough that prosecutors concealed exculpatory evidence at trial; the petitioner must also show that this evidence was material. ${ }^{143}$ A civil case asserting a Brady violation can only be brought after a conviction is vacated. ${ }^{144}$ At that phase, however, the context is now a post-conviction review of a final criminal conviction; the conviction has been overturned. I have argued elsewhere that, given this procedural posture, the materiality requirement is not applicable. ${ }^{145}$ Instead, under $\S 1983$, the question is whether the Brady violation caused a constitutional violation. ${ }^{146}$ Nevertheless,

140 See, e.g., NEB. REV. STAT. § 29-4505(1) (2016) ("If a defendant testifies contrary to his or her statement made during a custodial interrogation at a place of detention which was not electronically recorded, such statement may be used for the purpose of impeachment if it is shown that the statement was freely, knowingly, voluntarily, and intelligently made."); WIS. STAT. §972.115(2)(a) (2018) ("If a statement made by a defendant during a custodial interrogation is admitted into evidence in a trial for a felony before a jury and if an audio or audio and visual recording of the interrogation is not available, ... the court shall instruct the jury that it is the policy of this state to make an audio or audio and visual recording of a custodial interrogation of a person suspected of committing a felony and that the jury may consider the absence of an audio or audio and visual recording of the interrogation in evaluating the evidence relating to the interrogation and the statement in the case ...."); Commonwealth v. DiGiambattista, 813 N.E.2d 516, 534 (Mass. 2004) (“[T]he jury should also be advised that the absence of a recording permits (but does not compel) them to conclude that the Commonwealth has failed to prove voluntariness beyond a reasonable doubt.").

141 For a discussion of social science-informed reliability review of confession evidence, including through the use of expanded jury instructions, see Brandon L. Garrett, Contaminated Confessions Revisited, 101 VA. L. REv. 395, 399-419, 429-31 (2015).

142373 U.S. 83 (1963).

143 Id. at 87; see also United States v. Bagley, 473 U.S. 667, 682 (1985) (defining material evidence as that which creates "a reasonable probability that, had the evidence been disclosed to the defense, the result of the proceeding would have been different").

144 Heck v. Humphrey, 512 U.S. 477, 486-87 (1994).

145 Garrett, supra note 55, at 69-75.

146 See 42 U.S.C. $\$ 1983$ (2018). 
some federal courts have applied a "materiality and prejudice" standard, distinct from the civil causation standard, both in rulings on pretrial motions and in jury instructions, telling the jury that they must find a "reasonable probability" that the result of criminal proceedings would have been different if evidence had been disclosed. ${ }^{147}$ They have, in my view, mistakenly imported a criminal postconviction standard into a civil setting.

\section{MisPlaCED CONSTITUTIONAL INFLUENCE ON EXECUTIVES}

The prior Part focused on the unintended application of constitutional rules to the wrong procedural settings, such as in jury instructions or in the determination the admissibility of evidence at trial. This Part turns to the influence of such rulings on the wrong government actors, looking at when executive actors incorporate rules designed to limit remedies in civil cases to their own policies for executive conduct or for bringing criminal cases. All government officials should of course be carefully attentive to constitutional limits on their actions. However, they also should not treat constitutional floors as ceilings that they cannot improve upon by developing their own practices. Indeed, the Supreme Court has often been explicit that agencies are free to adopt their own policies and should do so to supplement the constitutional floor. I also describe how the Court may have intended to influence police behavior in the Fifth Amendment context post-Miranda, but I note that the effort has not been successful.

\section{A. Fourth Amendment Rulings and Police Use-of-Force Policies}

One place in which executive actors often adopt constitutional floors as ceilings is police use of force. There is a still more troubling aspect of the Supreme Court's qualified immunity rulings: they have impacted decisionmaking by police and prosecutors in other contexts. Those civil qualified immunity rulings have impacted prosecutors when deciding whether to criminally prosecute police for using deadly force. Timothy McGinty, in deciding not to prosecute the officer who shot Tamir Rice, cited extensively to the Supreme Court's ruling in City \& County of San Francisco v. Sheehan, ${ }^{148}$ a case finding that officers benefitted from qualified immunity. ${ }^{149}$ To the extent that the Court in Sheehan made statements regarding police tactics and not judging police with "the 20/20 vision of hindsight," those statements mixed the standard for judging force under the Fourth Amendment with the qualified immunity standards designed to protect "competent officers" from civil litigation, including litigation based solely on providing "an expert's report" on whether the officer's use of force was advisable. ${ }^{150}$ Such concern with the

147 See, e.g., Smith v. Holtz, 210 F.3d 186, 197 (3d Cir. 2000) (dismissing Brady claim because suppressed evidence was not material and not "sufficient to undermine confidence in the outcome" (quoting Bagley, 473 U.S. at 678)); see also Garrett, supra note 55, at 72.

148135 S. Ct. 1765 (2015).

149 See CuyAhoga RePort, supra note 18, at 39 (citing Sheehan, $135 \mathrm{~S}$. Ct. at 1765).

150 Sheehan, 135 S. Ct. at 1777 (quoting Billington v. Smith, 292 F.3d 1177, 1190 (9th Cir. 2002)). 
burdens of defending civil litigation, the uses of summary judgment, and the role of expert reports in civil litigation, all detailed in the Sheehan decision, should play no role when considering whether an officer committed a state crime.

More broadly, many prosecutors rely on civil Fourth Amendment case law when deciding whether to prosecute an officer for the use of force. As Seth Stoughton has put it: "The constitutional/non-constitutional and criminal/noncriminal lines are totally distinct here," and yet they have often been "very casually" imported from one context to the other. ${ }^{151}$ For federal officers, there is undoubtedly a separate and important Supremacy Clause concern in ensuring that federal law and institutions are insulated from state interference..$^{152}$ Executive actors are not constrained by civil Fourth Amendment case law when applying state criminal statutes and nor should they be, except to the extent that they must comply with the constitutional floor. While they may not cite to the Constitution disingenuously, they are not in fact bound to remain on the constitutional floor.

To be sure, executive actors can have a great deal of discretion. It may not be a legal error for such actors to rely on constitutional law in the sense that a court may use a standard in the wrong way as in the examples discussed. Nor do executive actors necessarily have to justify the exercise of their discretion; prosecutors do not have to justify their charging decisions, and police agencies can adopt the policies that they think are the most valuable in their patrol guides so long as they follow the constitutional minima. However, to the extent that actors adopt policies with reference to constitutional standards, I view it as problematic to cite to standards that do not necessarily apply in that setting without some further justification. Thus, if a prosecutor justified citing to a civil Fourth Amendment standard by emphasizing that even more than that would be required to justify a criminal prosecution, then perhaps that would be a sensible explanation for the usage. If an officer relies on constitutional authority that is not in fact applicable in a setting, then that officer has not properly justified a decision. The officer may have discretion, and there may not be a way to legally challenge the decision, but it should nevertheless be treated as suspect if there is a context in which it can be reviewed.

\section{B. Miranda and Police Policy}

The misuse of the Miranda standard at trial may be a symptom of a larger and understandable confusion regarding how that standard applies during police

${ }^{151}$ Leon Neyfakh, Tamir Rice's Killer Went Free Because of the "Reasonableness Test." It Didn't Have To Be That Way., SLATE (Dec. 31, 2015, 2:18 PM), https://slate.com/newsand-politics/2015/12/the-legal-reason-tamir-rices-killer-wasn-t-prosecuted.html [https://perma.cc/FS2A-LS94]; see also Chad Flanders \& Joseph Welling, Police Use of Deadly Force: State Statutes 30 Years After Garner, 35 St. LouIS U. Pub. L. ReV. 109, 126 (2015) ("The standards for criminal liability in a state criminal prosecution do not have to mimic the standards for a constitutional tort.").

${ }^{152}$ For an excellent discussion, see generally Seth P. Waxman \& Trevor W. Morrison, What Kind of Immunity? Federal Officers, State Criminal Law, and the Supremacy Clause, 112 YALE L.J. 2195 (2003). 
interrogations. The Supreme Court's rulings in the Miranda context and in related Fifth Amendment contexts make it difficult for law enforcement not only to sensibly follow Miranda itself but also to adopt a coherent body of best practices that might improve upon the constitutional floor. Where the Court does so, it is harder to identify a clearly misplaced use of constitutional doctrine; the Court may very well be trying to regulate, or at least influence, executive actors.

In such situations, police agencies are free to move beyond the constitutional framework set out in Supreme Court decisions and supplement it with their own rules and approaches. It is not a misplacement, or clearly wrong, for executive actors to adhere to the constitutional floor, so long as they choose to do so. A reflexive adherence, due to mistaken understanding or lack of realization that they can build on that floor, however, would be more troubling. Over time, agencies may increasingly depart from the constitutional floor if it is not informative. That has occurred in the interrogation context, as is discussed below. One reason for this departure may be due to a genuine concern that false confessions can result from following an approach that unduly permits uninformed and coercive interrogations. However, for other agencies, another reason to adopt improved practices may have been that those constitutional rulings have become so complex and incoherent that the system is not worth gaming.

The Supreme Court's Fifth Amendment totality-of-the-circumstances test does not provide useful guidance to law enforcement, creating a body of law that is both in tension with the Miranda ruling and difficult to follow. The rulings suggest that, absent a suspect deemed to be in custody, no regulation or guidance is necessary for police. Yet what "custody" entails is often hard to predict or understand. Thus, in rulings such as Salinas v. Texas, ${ }^{153}$ the Supreme Court has been highly tolerant of police questioning of individuals deemed not to be in "custody" without providing Miranda warnings and the accompanying constitutional protections. ${ }^{154}$

Similarly, the Supreme Court's Fifth Amendment "voluntariness" test provides a remedy for undue coercion during custodial interrogations. ${ }^{155}$ However, that test is multifactored and highly case specific, and it does not provide clear guidance to law enforcement. ${ }^{156}$ Courts have upheld the constitutionality of, for example, extremely lengthy interrogations. ${ }^{157}$ Indeed,

153570 U.S. 178 (2013) (plurality opinion).

${ }^{154} \mathrm{Id}$. at 181 (affirming judgment against defendant where defendant was not in custody, did not receive Miranda warnings, and did not invoke right against self-incrimination).

155 Arizona v. Fulminante, 499 U.S. 279, 302 (1991) (remanding case for new trial at which confession is not admitted as evidence when confession was coerced by threat of violence).

156 Eve Brensike Primus, The Future of Confession Law: Toward Rules for the Voluntariness Test, 114 MicH. L. REV. 1, 3 (2015).

157 Welsh S. White, What Is an Involuntary Confession Now?, 50 RUTGERS L. REV. 2001, 2046-47 (1998) (discussing effect of lengthy interrogations on voluntariness of confessions and citing cases in which courts have nonetheless upheld interrogations lasting nine or more hours). 
the Supreme Court has itself noted that the voluntariness test does not provide clear guidance to law enforcement. In Dickerson, it stated that "the totality-ofthe-circumstances test ... is more difficult than Miranda for law enforcement officers to conform to, and for courts to apply in a consistent manner." ${ }^{158}$ Or as the Court put it far earlier in Haynes $v$. Washington, ${ }^{159}$ "The line between proper and permissible police conduct and techniques and methods offensive to due process is, at best, a difficult one to draw . ..."160

The Court has said that "[ $\mathrm{t}] \mathrm{he}$ main purpose of Miranda is to ensure that an accused is advised of and understands the right to remain silent and the right to counsel," and the Miranda rule can be said to provide a simple rule of decision for police: provide the warnings or be deprived of the use of statements that follow the police questioning. ${ }^{161}$ Rather than retain a simple rule to guide police, though, the Court has held that a waiver of rights may be "implied" from silence, even after several hours of a suspect remaining silent in the face of police questioning. ${ }^{162}$ The Court has permitted "a good-faith Miranda mistake" to excuse an officer's failure to provide the warnings in a departure from prior rulings that typically imposed an objective standard of care upon officers. ${ }^{163}$ The standards and distinctions in this area of law are complex. Barry Friedman has described these rulings as "stealth overruling," where without explicitly overruling it, the Court's subsequent rulings do not appear faithful to the Miranda decision. ${ }^{164}$ These complex rulings create opportunities for gaming the system rather than providing law enforcement with a clear set of best practices for interviews and interrogations.

The concern shared by many scholars is that the result of this case law was to encourage police agencies to adopt the constitutional baseline which permits the flouting of Miranda and related Fifth Amendment law by making use of exceptions and by generally deemphasizing Miranda warnings, making them seem like an irrelevant afterthought in order to see that such warnings are disregarded by the subject. ${ }^{165}$

158 Dickerson v. United States, 530 U.S. 428, 444 (2000).

159373 U.S. 503 (1963).

${ }^{160}$ Id. at 515.

161 Berghuis v. Thompkins, 560 U.S. 370, 383 (2010).

162 Id. at 384 ("Butler made clear that a waiver of Miranda rights may be implied through 'the defendant's silence, coupled with an understanding of his rights and a course of conduct indicating waiver.'” (quoting North Carolina v. Butler, 441 U.S. 369, 373 (1979))).

163 Missouri v. Seibert, 542 U.S. 600, 615 (2004) (plurality opinion) ("Although the Elstad Court expressed no explicit conclusion about either officer's state of mind, it is fair to read Elstad as treating the . . conversation as a good-faith Miranda mistake, not only open to correction by careful warnings before systematic questioning ..., but posing no threat to warn-first practice generally." (citing Oregon v. Elstad, 470 U.S. 298, 309 (1985))).

164 Barry Friedman, The Wages of Stealth Overruling (with Particular Attention to Miranda v. Arizona), 99 GEO. L.J. 1, 16-25 (2010).

165 Richard A. Leo \& Welsh S. White, Adapting to Miranda: Modern Interrogators' Strategies for Dealing with the Obstacles Posed by Miranda, 84 MinN. L. REV. 397, 433-39 (1999). 
Commonly used interrogation tactics themselves seem to violate the spirit of this case law. American police interrogators long used the so-called "Reid Method."166 "[This] method emphasizes a set of psychological techniques designed to confront and accuse a suspect, and then maximize the pressure placed on the suspect to incriminate themselves, while appearing to minimize the consequences for the suspect in doing so." 167 The techniques tend to rely on "some form of deception," ranging from "rationalization" of the person's actions to outright "evidence fabrication." 168 Perhaps, though, the Supreme Court over time, in "stealth overruling" Miranda, used its rulings to encourage agencies to adopt such approaches. The Court's rulings may have tacitly encouraged highly coercive interrogation tactics. If so, then this was not the Court standing by as its constitutional rulings were misapplied. Instead, the Court intended and encouraged police use of its more recent rulings (like those creating exceptions to Miranda) to replace reliance on its older rulings like Miranda.

However, the story is more complex still because the Supreme Court may not have accomplished what it intended. Arguably due to the confusing guidance provided by the more recent decisions, the message they have sent may have been lost on policing agencies. Traditional interrogation methods have been evolving in the United States; Wicklander-Zulawski \& Associates, perhaps the leading interrogation training provider, no longer trains on the Reid Method. ${ }^{169}$ The federal High-Value Detainee Interrogation Group ("HIG"), which includes members of the CIA, FBI, and other federal law enforcement, has developed interrogation best practices that similarly focus on questioning that is designed to build rapport and "draw out what the detainee knows as opposed to only focusing on [what] the intelligence the team would like to obtain." 170 "Police departments, including in Dallas, Philadelphia, and Los Angeles, have begun to use the approach developed by the HIG." ${ }^{171}$ Recording police interrogations, an approach neither encouraged nor discouraged by federal constitutional rulings, has become extremely common; it has been voluntarily adopted by police

166 Fred E. Inbau, John E. Reid, Joseph P. Buckley \& Brian C. Jayne, Criminal INTERROGATION AND CONFESSIONS 339-50 (5th ed. 2013) (discussing Reid Method on how to distinguish between true and false confessions).

167 Principles OF THe LaW: Policing $\S 11.01$, at 104 (AM. LAw InST., Tentative Draft No. 2, 2019).

168 Christopher Slobogin, Manipulation of Suspects and Unrecorded Questioning: After Fifty Years of Miranda Jurisprudence, Still Two (or Maybe Three) Burning Issues, 97 B.U. L. REV. 1157, 1160-61 (2017).

169 Eli Hager, The Seismic Change in Police Interrogations, MARSHALl ProjeCt (Mar. 7, 2017, 10:00 PM), https://www.themarshallproject.org/2017/03/07/the-seismic-change-inpolice-interrogations [https://perma.cc/SX3V-6J37].

${ }^{170}$ High-Value Detainee Interrogation Grp., Interrogation Best Practices 2 (2016), https://www.fbi.gov/file-repository/hig-report-august-2016.pdf/view [https://perma.cc/S5FC-UVAJ].

171 Principles of the LaW: Policing $§ 11.01$, at 104 (AM. LAW InST., Tentative Draft No. 2, 2019). 
agencies, required or encouraged by model policies, required by state statutes, and required or encouraged by state court rulings. ${ }^{172}$

The Supreme Court may have nudged its constitutional floor in the direction of a ceiling, ${ }^{173}$ but over time that effort may have failed. Increasingly, police agencies and state court rulings nevertheless treat those rulings as a floor that they should build upon. In that way, the experience of the adoption and nonadoption of constitutional law concerning police interrogations is a hopeful one. Over time, executive actors can learn from their experience in using constitutional rules and can make more informed decisions about whether and how to rely upon those constitutional rules.

\section{Eyewitness Identification Procedure}

In the jury instruction area, state courts, police agencies, and lawmakers in recent years have increasingly stepped away from the Manson decision when crafting reformed jury instructions and police practices in the area of eyewitness identifications. They have (correctly in my opinion) come to the view that the constitutional rule is only a floor and not a ceiling. In doing so, they have cited to more recent scientific research as a reason to revise or update the manner in which the judge explains the "reliability" of an eyewitness identification to the jury. ${ }^{174}$ As the National Academy of Sciences has put it: "The best guidance for legal regulation of eyewitness identification evidence comes not... from constitutional rulings, but from the careful use and understanding of scientific evidence to guide fact-finders and decision-makers." ${ }^{175}$

172 Thomas P. Sullivan \& Andrew W. Vail, The Consequences of Law Enforcement Officials' Failure to Record Custodial Interviews As Required by Law, 99 J. CRIM. L. \& CRIMINOLOGY 215, 228-34 (2009) (listing police departments that employ video recording in every state and the District of Columbia); see also Saul M. Kassin, Richard A. Leo, Christian A. Meissner, Kimberly D. Richman, Lori H. Colwell, Amy-May Leach \& Dana La Fon, Police Interviewing and Interrogation: A Self-Report Survey of Police Practices and Beliefs, 31 LAW \& HuM. BEHAV. 381, 382 (2007) (listing observation of taped interrogations as basis for empirical study); Principles of THE LAW: Policing $§ 11.02$, at 109-12 (AM. LAW InST., Tentative Draft No. 2, 2019).

173 Indeed, scholars who are critical of Miranda because they view it as overly regulating police and those who believe it did not go nearly far enough agree that moving away from Supreme Court case law has been a positive development. See, e.g., Paul G. Cassell, Protecting the Innocent from False Confessions and Lost Confessions-and from Miranda, 88 J. CRIM. L. \& CRIMINOLOGY 497, 503 (1998) ("To protect the innocent, videotaping of police interrogation should be substituted for the Miranda rules."); Richard A. Leo, Peter J. Neufeld, Steven A. Drizin \& Andrew E. Taslitz, Promoting Accuracy in the Use of Confession Evidence: An Argument for Pretrial Reliability Assessments to Prevent Wrongful Convictions, 85 TEMP. L. Rev. 759, 790 (2013) ("Miranda fails to offer any meaningful protection against the elicitation of false confessions or the admission of false and unreliable confessions into evidence at trial.").

${ }^{174}$ For a detailed discussion of state jury instructions in this area and their evolution, see NRC REPORT, supra note 15 , at 40-43.

175 Id. at 44. 
The most dramatic shift in any state court occurred in 2011, when the New Jersey Supreme Court issued a unanimous decision in State v. Henderson. ${ }^{176}$ In 2012, that court released an expanded jury instruction, a new court rule, and a revised court rule relating to eyewitness identifications in criminal cases. ${ }^{177}$ The jury instruction contains a highly detailed set of factors that, if implicated in a given case, are to be used to explain to jurors how to assess eyewitness identification evidence. ${ }^{178}$ The Oregon Supreme Court in its State v. Lawson ${ }^{179}$ decision instead rejected Manson as useful as a matter of state evidence law, relying instead on an analysis similar to that under Federal Rule of Evidence 403 to rule that scientific evidence should inform the question of whether an eyewitness identification should be excluded as unduly prejudicial or whether cautionary instructions are warranted. ${ }^{180}$ The third state high court to intervene has been the Massachusetts Supreme Judicial Court, which, in Commonwealth v. Gomes, ${ }^{181}$ recently adopted a far more concise jury instruction that conveys similar information about scientific research on eyewitness memory. ${ }^{182}$ The National Academy of Sciences report counseled that more research needs to be done to study what types of jury instructions are effective and that use of expert testimony is preferable; the report added that, as a second-best alternative, judges should provide a concise set of instructions that is easily understandable to a jury. ${ }^{183}$

A few other courts have rejected the Manson approach in part, making piecemeal improvements to their evidentiary rules. The Georgia Supreme Court concluded in 2005 that one particular use of the Manson factors was no longer to be permitted, stating, "[W]e can no longer endorse an instruction authorizing

17627 A.3d 872, 928 (N.J. 2011) (modifying framework for evaluating reliability of eyewitness testimony based on scientific evidence).

177 See N.J. CT. R. 3:11 (explaining requirements for out-of-court suspect identification procedure); N.J. CT. R. 3:13-3 (rendering discoverable in a criminal proceeding all records related to identification procedures); N.J. COURTS, MODEL CRIMINAL JURY ChaRges, IDENTIFICATION: IN-COURT AND OUT-OF-COURT IDENTIFICATIONS 2-8 (2012) [hereinafter N.J. MODEL CRIMINAL INSTRUCTIONS], https://www.njcourts.gov/attorneys/assets/criminalcharges /idinout.pdf [https://perma.cc/MXK5-WEYA] (setting forth jury charges explaining to jurors scientific research on accuracy of memory).

178 N.J. MOdel CRIMINAL InSTRUCTIONS, supra note 177, at 2-8.

179291 P.3d 673 (Or. 2012) (en banc).

${ }^{180} \mathrm{Id}$. at $690-97$ (concluding that the Manson framework is inadequate and describing revised procedures).

18122 N.E.3d 897 (Mass. 2015).

${ }^{182}$ Id. at 918-27 (setting forth provisional model jury instruction).

183 See NRC REPORT, supra note 15, at 42-43 ("Expert testimony on eyewitness memory ... appears to have many advantages ... . However, when expert testimony is not available ..., jury instructions may be a preferable alternative means to inform the jury of the findings of scientific research . . . . Brief instructions may not, however, provide sufficient guidance to explain the relevant scientific evidence to the jury, but lengthy instructions may be cumbersome and complex. More research is warranted to better understand how best to communicate to jurors the factors that may affect the validity of eyewitness testimony ...."). 
jurors to consider the witness's certainty in his/her identification as a factor to be used in deciding the reliability of that identification." 184 Other courts have done the same, modifying the Manson factors by discarding from jury instructions any instruction as to eyewitness confidence or certainty. ${ }^{185}$ Like the Third Circuit, the First Circuit Court of Appeals recently endorsed more detailed instructions concerning cross-racial identifications, identification under stress, the relevance of witness confidence, and use of suggestive identification practices. ${ }^{186}$

Traditionally, many law enforcement agencies either had policies that were decades out of date or had no written policies at all; the brief policies that did exist often simply restated federal constitutional law. ${ }^{187}$ Often, any training that these agencies conducted was informal. ${ }^{188}$ Many agencies had policies that largely repeated what the federal due process test states about avoiding undue suggestion in lineups. ${ }^{189}$ As in the interrogation setting, however, that may be changing. There is evidence, for example, that model policies can encourage agencies to adopt more evidence-informed approaches towards lineups. ${ }^{190}$ In recent years, there is evidence that more police agencies have adopted revised eyewitness identification policies. ${ }^{191}$

184 Brodes v. State, 614 S.E.2d 766, 771 (Ga. 2005).

185 See, e.g., Commonwealth v. Payne, 690 N.E.2d 443, 448 (Mass. 1998) (“[W] recently held ... that language telling the jury to take into account the strength of the identification 'should be omitted from the standard instruction concerning eyewitness testimony'...." (quoting Commonwealth v. Santoli, 680 N.E.2d 1116, 1121 (Mass. 1997))); State v. Romero, 922 A.2d 693, 703 (N.J. 2007) (“[A] witness's level of confidence, standing alone, may not be an indication of the reliability of the identification." (emphasis omitted)).

186 United States v. Jones, 689 F.3d 12, 19-20 (1st Cir. 2012) ("[W]e agree that ... information bearing on the effects of stress, witness confidence and cross-racial identification would be helpful to the jury in the present case ....”). Updated First Circuit pattern jury instructions reflecting those additions cited to guidance from the American Bar Association and from the Henderson decision in New Jersey. NANCY TORRESEN, U.S. District Court District of Maine, 2019 Revisions to Pattern Criminal Jury Instructions For the District COURTS OF THE First Circuit $\S 2.22$ (2019), https://www.med.uscourts.gov/pdf/crpjilinks.pdf [https://perma.cc/WW7N-EU6A].

187 See, e.g., Police Exec. Research Forum, A National Survey of Eyewitness IdENTIFICATION Procedures IN LAW ENFOrCEMENT Agencies 46-47 (2013), https://www.policeforum.org/assets/docs/Free_Online_Documents/Eyewitness_Identificatio n/a $\% 20$ national $\% 20$ survey $\% 20$ of $\% 20$ eyewitness $\% 20$ identification $\% 20$ procedures $\% 20 \mathrm{in} \% 2$ 0law\%20enforcement\%20agencies\%202013.pdf [https://perma.cc/Q7XR-FUEN].

188 Michael S. Wogalter, Roy S. Malpass \& Dawn E. McQuiston, A National Survey of US Police on Preparation and Conduct of Identification Lineups, 10 PSYCHOL. CRIME \& L. 69, 79 (2004) (finding that, of 220 agencies surveyed, over half reported no formal training on eyewitness identification procedures).

189 Id.

190 Albright \& Garrett, supra note 10, at 52-56 (describing adoption of model policies regarding eyewitness evidence in twenty-nine states and the federal government).

191 Brandon L. Garrett, Eyewitness Identifications and Police Practices: A Virginia Case Study, 2 VA. J. CRIM. L. 1, 18 (2014) (finding that few Virginia law enforcement policies 
State lawmakers have required that police agencies adopt a series of best practices in their identification policies. ${ }^{192}$ When state statutes are not informed by constitutional rules, the drafters may have shied away from permitting clear remedies in court since they cannot point to a due process violation requiring exclusion if agencies do not comply. ${ }^{193}$ If so, they should not have been so focused on federal constitutional law as a model.

\section{Avoiding Misplaced Constitutional LaW}

The examples discussed in the previous Part include rules relevant to both civil and criminal cases, rules governing judges and executive actors, and rules informing lawmakers. The ramifications of each example extend beyond cases that go to trial, since they may affect civil settlement and plea bargaining in the vast majority of cases that do not proceed to trial. What can better prevent the use of constitutional language in evidentiary contexts for which it was not intended? I suggest that far more care should be paid both to the interpretation of constitutional rights that affect evidence practice and to evidence practice itself. What that care means depends on who the actor is; courts may be quite constrained to appropriately employ constitutional standards, while executive actors may have quite a bit of discretion. It may merely be advisable to correctly cite to and explain the use of a constitutional standard. I also describe lessons learned from efforts to intentionally use constitutional rules to influence courts and executive actors, such as the cautionary post-Miranda story described in Part III.

\section{A. Clear Statement Rules}

One way to address the misplacement problem is to insist that courts more clearly state to which actor, procedural setting, or remedy a constitutional right is addressed. Such a rule could be seen as a type of clear statement rule. Rather than require, say, lawmakers to clearly state whether they seek to achieve a result that implicates a constitutional right, this type of rule would require a clear statement that an actor intends to rely on constitutional text in a new setting. ${ }^{194}$ Courts should explain that a constitutional right is designed with an actor or setting or remedy in mind, and they should step in if actors use constitutional language in unintended ways. Not only should they make clear statements that they intend to displace state or administrative law, but courts should engage in

complied with state model policy on lineup procedures). But see Brandon L. Garrett, SelfPolicing: Dissemination and Adoption of Police Eyewitness Policies in Virginia, 105 VA. L. REV. ONLINE 96, 109 (2019) (describing widespread adoption of state model policy since 2014 study).

192 Albright \& Garrett, supra note 10, at 47-52.

193 Id. at app. A (appendix on file with the Boston University Law Review) (detailing each of these state statutes and noting that none requires judicial remedies for violations).

194 Manning, supra note 73, at 401 (describing such clear statement rules which "insist that Congress express itself clearly when it wishes to adopt a policy that presses against a favored constitutional value"). 
careful consideration before awarding deference to or using constitutional rights and norms in contexts in which they do not formally apply.

One challenge is that the constitutional problem is less visible when courts claim to be adhering to a constitutional test but are in fact using that test for different or even inconsistent purposes. It can seem cautious to rely on constitutional text when in doubt. Soliciting briefs on trial and evidentiary practice could perhaps better inform such rulings, and lower courts may be better able to assess the practical problems posed. Doing this can also create, I have suggested, more incentives for lower courts to document rulings and model rulings and instructions, creating a record and making it easier for other courts to know to what evidentiary uses constitutional rulings are put. ${ }^{195}$

When courts or executive actors cite to and rely upon constitutional standards, one abiding lesson should be that recitation of constitutional language should not be enough. Deference to constitutional law and norms should not be automatic when not required or even intended. Careful attention should be paid to whether that constitutional test is serving its purpose when extended into a new context.

Thus, when state courts adopt the federal rule for a constitutional right, observers should ask whether they should rather have built upon the constitutional floor rather than just hewed to the minimum. They are not misplacing a constitutional right; the federal minimum does apply, but it does not constrain them from doing more. All too often though, states have adopted federal standards without serious justification for doing so. ${ }^{196}$ Similarly, judges, when crafting jury instructions or in their own rulings, may parrot a constitutional standard rather than considering what standard suits the problem. The adoption of a standard by the Supreme Court can simply disincentivize government actors from further regulating an area. ${ }^{197}$ The costs to sound policy can be substantial and unintended.

195 See Garrett, supra note 1, at 117.

196 See, e.g., Chelf v. Civil Serv. Comm'n, 515 N.W.2d 353, 356 (Iowa Ct. App. 1994) (finding that state law supports objective approach to determining whether officer used excessive force but deriving standard from Graham v. Connor rather than state law sources); Caudillo v. City of Phoenix, No. 1 CA-CV 09-0467, 2010 WL 2146408, at *4 n.6 (Ariz. Ct. App. May 27, 2010) ("It appears ... that [the officer] was 'effectuating an arrest' because his use of deadly force against Celaya constituted a seizure for Fourth Amendment purposes."). But see Hayes v. Cty. of San Diego, 305 P.3d 252, 263 (2013) (finding that "state negligence law ... is broader than federal Fourth Amendment law"); SETH W. STOUGHTON, JeFFREY J. Noble \& Geoffrey P. Alpert, Evaluating Police Uses of Force 70-71 (2020) (“Thirtytwo states, a significant majority, have simply not referenced constitutional law when interpreting or applying state law in the context of deadly force ....").

197 William J. Stuntz, The Political Constitution of Criminal Justice, 119 HARV. L. REV. 781,793 (2006). 


\section{B. Common Placement}

The misplacement of constitutional tests, as described in this Article, raises a larger question of the use of one line of constitutional interpretation to influence another area of doctrine. So-called constitutional "borrowing" may sometimes be quite appropriate and desirable, but sometimes is not. ${ }^{198}$ In some areas, while the constitutional text arguably does not cover a different actor, remedy, or procedural context, the Supreme Court may have interpreted the right as applying in that other setting.

This type of convergence may not necessarily be problematic at all if similar interests are served in the other setting. For example, the Sixth Amendment right to counsel, as noted, has been interpreted as applying to only critical phases of a criminal trial. ${ }^{199}$ However, the Court has ruled that on appeal, there are similar due process and equal protection rights to counsel, with similar rights to effective assistance of counsel and to representation for an indigent defendant. ${ }^{200}$ Similarly, while the right of confrontation under the Sixth Amendment applies only in criminal cases, the Supreme Court has held that juveniles have a similar right in juvenile cases under the due process and equal protection clauses. ${ }^{201}$ The goals of those other amendments may overlap, providing analogous protections. Importantly, the Court has been clear that the juveniles' right to counsel rests on different constitutional grounds than the Sixth Amendment, showing how there may be different sources for protection in contexts not covered by a certain constitutional right. As such, the Court may borrow standards or approaches, but it does not formally misplace one standard in a different context.

That said, even if there is a good reason for a constitutional rule to influence a setting in which it is not formally binding, the rule must also be adapted to that setting. I have described how the Supreme Court's post-Miranda rulings are so complex that they provide poor guidance to law enforcement. They are not fit for that setting because officers require clear policy and training. Similarly, as described next, jury instructions may not be well adapted to reflect the types of considerations that inform constitutional rights, since they are typically designed to inform jurors about the type and weight of evidence they should consider and not whether a person's rights were violated.

198 See Nelson Tebbe \& Robert L. Tsai, Constitutional Borrowing, 108 Mich. L. REV. 459, 467-71 (2010) (juxtaposing benefits of constitutional borrowing with risks thereof, such as creating legal discordance).

199 Kirby v. Illinois, 406 U.S. 682, 690 (1972).

${ }^{200}$ Halbert v. Michigan, 545 U.S. 605, 617-24 (2005); Martinez v. Court of Appeal, Fourth Appellate Dist., 528 U.S. 152, 155 (2000) ("The right to counsel on appeal stems from the due process and equal protection clauses of the Fourteenth Amendment, not from the Sixth Amendment ....” (quoting People v. Scott, 75 Cal. Rptr. 2d 315, 318 (Ct. App. 1998))).

201 In re Gault, 387 U.S. 1, 57 (1967) ("[A]bsent a valid confession, a determination of delinquency and an order of commitment to a state institution cannot be sustained in the absence of sworn testimony subjected to the opportunity for cross-examination in accordance with our law and constitutional requirements."). 


\section{Rethinking Jury Instructions}

The use of constitutional rights in jury instructions - and in evidentiary practice more generally - is a subject that deserves far more attention in the bar and in scholarship. However, it is a challenge to get good information about what those uses are, and it will always be a challenge to secure better practice in the courts. One of many underlying practical problems is that model jury instructions do not exist in some jurisdictions, and in many, the pattern instructions are not always followed, infrequently updated, and assembled by court-convened or bar committees with an informal or nontransparent process. Jury instructions may only be called into question if a judge fails to conform to a constitutional standard. As a result, judges err on the side of using "technically correct legal language," even if it may be incomprehensible to lay jurors. ${ }^{202}$ Parroting constitutional rulings may seem like good insurance against appellate reversal. Jury instructions may be called into question when they become decades out of date and controversial, but the pace of change is often quite slow.

Far more attention should be paid to whether constitutional rulings are actually implemented in evidentiary practice - in rules of evidence, in judicial rulings, and in jury instructions. Trial error is commonly not preserved on appeal, making poor compliance hard to remedy in the courts. Overuse of a constitutional test may be harder to detect or less glaring than outright violations of constitutional dictates. One of the main goals of this Article is to bring to light the fact that unintended misplacement of constitutional language can pose serious problems as well.

Indeed, while it is not an example of constitutional language being misplaced in jury instructions, a related problem exists in the area of qualified immunity. In a broad set of remedial restrictions set out by the Supreme Court, executive officials may benefit from qualified immunity as a defense from a constitutional suit. ${ }^{203}$ In a constitutional tort case brought under $\S 1983$, official defendants may assert qualified immunity as a defense; most are not entitled to "absolute" immunity from suit. ${ }^{204}$ The first question is whether "the officer's conduct violated a constitutional right." 205 Second, the test asks whether an objectively reasonable officer in the defendant's position would have acted that way given clearly established constitutional law at the time. ${ }^{206}$ In some cases, unresolved

${ }^{202}$ Wylie A. Aitken, Comment, The Jury Instruction Process-Apathy or Aggressive Reform?, 49 MARQ. L. REV. 137, 139 (1965).

203 See Harlow v. Fitzgerald, 457 U.S. 800, 807 (1982).

${ }^{204}$ Id.

205 Saucier v. Katz, 533 U.S. 194, 201 (2001), overruled by Pearson v. Callahan, 555 U.S. 223, 236, 242-43 (2009) (relaxing Saucier's two-step inquiry for determining whether qualified immunity applies such that the order is "no longer . . . regarded as mandatory").

206 Pearson, 555 U.S. at 236-37; Hope v. Pelzer, 536 U.S. 730, 741 (2002) (stating that unlawfulness can be apparent "even in novel factual circumstances"); Anderson v. Creighton, 483 U.S. 635, 640 (1987) ("The contours of the right must be sufficiently clear that a reasonable official would understand that what he is doing violates that right. This is not to say that an official action is protected by qualified immunity unless the very action in question 
questions of fact will make it impossible for the judge to rule on qualified immunity before the time of trial. ${ }^{207}$ The purposes of qualified immunity dissipate "once a claim has reached a jury trial, [because] concerns about discovery and summary judgment are moot." 208

Thus, qualified immunity doctrine attaches to particular officers-namely executive officers - and at particular stages in particular proceedings - namely pretrial motion to dismiss and summary judgment dispositions in civil damages trials. As a result, it would be erroneous to rely on the Supreme Court's qualified immunity law in a criminal proceeding or regarding a nonexecutive official (such as a judge, for whom the Court has ruled absolute immunity attaches). ${ }^{209}$ Moreover, federal judges often misplace these qualified immunity standards at trial instead of just using them during pretrial. For example, they do so when instructing juries in $\S 1983$ suits based on Fourth Amendment excessive force claims. ${ }^{210}$ The Fourth Amendment constitutional standard of reasonableness itself involves a complex underlying body of case law, adopting a flexible set of principles that state that officers generally may not use unreasonable force but with exceptions depending on the circumstances they face. ${ }^{211}$ As Rachel Harmon has put it, the jury instructions in the area "sometimes provide exceptionally little help in shaping a determination about excessiveness." 212 Additional considerations regarding the legal question of qualified immunity make the subject still more complex. Questions relating to qualified immunity should not be put to the jury "routinely"; rather, as the Supreme Court has said, "Immunity ordinarily should be decided by the court long before trial." 213

has previously been held unlawful, but it is to say that in the light of pre-existing law the unlawfulness must be apparent." (citation omitted)); Malley v. Briggs, 475 U.S. 335, 341 (1986) (finding that qualified immunity defense may apply "if the defendant acted in an objectively reasonable manner"); Harlow, 457 U.S. at 818 ("We therefore hold that government officials performing discretionary functions, generally are shielded from liability for civil damages insofar as their conduct does not violate clearly established statutory or constitutional rights of which a reasonable person would have known.").

207 See, e.g., Curley v. Klem, 298 F.3d 271, 278 (3d Cir. 2002).

${ }^{208}$ U.S. COURT OF APPEALS FOR THE THIRD Circuit, Instructions FOR Civil Rights Claims Under SeCtion $1983 \S 4.7 .2$, at 66 (2014) [hereinafter ThiRD Circuit CiviL INSTRUCTIONS], https://www.ca3.uscourts.gov/sites/ca3/files/4_Chap_4_2014_fall.pdf [https://perma.cc/L93C-EANF].

209 Pierson v. Ray, 386 U.S. 547, 553-54 (1967).

210 See supra Section III.A.

211 Saucier, 533 U.S. at 205 ("Because 'police officers are often forced to make splitsecond judgments - in circumstances that are tense, uncertain, and rapidly evolving - about the amount of force that is necessary in a particular situation,' the reasonableness of the officer's belief as to the appropriate level of force should be judged from that on-scene perspective." (citation omitted) (quoting Graham v. Connor, 490 U.S. 386, 397 (1989)).

212 Rachel A. Harmon, When Is Police Violence Justified?, 102 Nw. U. L. REv. 1119, 1144-45 (2008).

${ }^{213}$ Hunter v. Bryant, 502 U.S. 224, 228 (1991) (per curiam). 
To be sure, a judge can reverse on summary judgment until after a jury verdict, but that is different than using qualified immunity as a standard that jurors are obligated to employ when they reach their verdict. Some courts have held that "[i]t is error, however, to submit the ultimate question of qualified immunity to the jury." 214 The rationale is that "[t]he issue of qualified immunity is a question of law for the court, rather than the jury, to decide: '[I]t is the province of the jury to determine disputed predicate facts, the question of qualified immunity is one of law for the court." 215 But there remains "a split among the circuits as to the proper apportionment of responsibility between juries and judges in this context." 216 The Fifth Circuit has long held that "if [qualified immunity] is not decided until trial the defense goes to the jury which must then determine the objective legal reasonableness of the officers' conduct." 217

${ }^{214}$ Littrell v. Franklin, 388 F.3d 578, 586 (8th Cir. 2004).

${ }^{215} \mathrm{Id}$. at 584-85 (second alteration in original) (quoting Peterson v. City of Plymouth, 60 F.3d 469, 473 n.6 (8th Cir. 1995)).

${ }^{216}$ Id. at 587; see also, e.g., Curley v. Klem, 499 F.3d 199, 211 (3d Cir. 2007) (“[W]hether an officer made a reasonable mistake of law and is thus entitled to qualified immunity is a question of law that is properly answered by the court, not a jury. When a district court submits that question of law to a jury, it commits reversible error." (citation omitted)); Willingham v. Crooke, 412 F.3d 553, 560 (4th Cir. 2005) (holding that the court should submit any questions of material fact to the jury but reserve legal question of qualified immunity for itself); Riccardo v. Rausch, 375 F.3d 521, 526 (7th Cir. 2004) ("Immunity . . is a matter of law for the court, to be decided without deference to the jury's resolution - and preferably before the case goes to the jury."); Cowan ex rel. Estate of Cooper v. Breen, 352 F.3d 756, 764 (2d Cir. 2003) ("[A]lthough the factual disputes in the instant case that must be resolved by the jury go both to the excessive force and to the qualified immunity questions, the qualified immunity issue is 'a question of law better left for the court to decide."' (quoting Warren v. Dwyer, 906 F.2d 70, 76 (2d Cir. 1990))); Suboh v. Dist. Att'y's Office, 298 F.3d 81, 90 (1st Cir. 2002) (stating that questions in qualified immunity inquiry are issues of law, though they may entail preliminary factual determinations); Johnson v. Breeden, 280 F.3d 1308, 1318 (11th Cir. 2002) ("When the case goes to trial, the jury itself decides the issues of historical fact that are determinative of the qualified immunity defense, but the jury does not apply the law relating to qualified immunity to those historical facts it finds; that is the court's duty."); Alvarado v. Picur, 859 F.2d 448, 451 (7th Cir. 1988) (rejecting jury instruction that told jurors that defendants would be immune if their actions did not violate clearly established law, querying "[h]ow was the jury supposed to determine the law on the dates in question? And, if the jury somehow could determine the law on the dates in question, how was it supposed to determine if that law was 'clearly established'?"); McIntosh v. Weinberger, 810 F.2d 1411, 1431 n.8 (8th Cir. 1987) ("The court, rather than the trier of fact, is to determine "whether the facts alleged ... support a claim of violation of clearly established law." (quoting Mitchell v. Forsyth, 472 U.S. 511, 528 n.9 (1985) (alteration in original))), vacated and remanded sub nom. Turner v. McIntosh, 487 U.S. 1212 (1988). But see McCardle v. Haddad, 131 F.3d 43, 50 (2d Cir. 1997) ("Where the qualified immunity defense has not been resolved prior to trial, it may be presented to the jury or it may be decided by the court as a matter of law.").

${ }^{217}$ McCoy v. Hernandez, 203 F.3d 371, 376 (5th Cir. 2000); accord Keylon v. City of Albuquerque, 535 F.3d 1210, 1218 (10th Cir. 2008) ("[I]n exceptional circumstances 
Pattern jury instructions reflect these differences. ${ }^{218}$ There is also the separate question of whether it may mislead jurors to hear additional instructions granting

historical facts may be so intertwined with the law that a jury question is appropriate as to whether a reasonable person in the defendant's position would have known that his conduct violated that right." (quoting Maestas v. Lujan, 351 F.3d 1001, 1007 (10th Cir. 2003))); Champion v. Outlook Nashville, Inc., 380 F.3d 893, 900 (6th Cir. 2004) ("[W]here the legal question of qualified immunity turns upon which version of the facts one accepts, the jury, not the judge, must determine liability." (quoting Pouillon v. City of Owosso, 206 F.3d 711, 715 (6th Cir. 2000))); Sikes v. Gaytan, 218 F.3d 491, 493-94 (5th Cir. 2000) (allowing single jury instruction on issues of liability and qualified immunity); Ortega v. O'Connor, 146 F.3d 1149, 1156 (9th Cir. 1998) (holding that, where factual disputes existed, qualified immunity question required jury's determination); Snyder v. Trepagnier, 142 F.3d 791, 800 (5th Cir. 1998) ("So, "if . . . there remain disputed issues of material fact relative to immunity, the jury, properly instructed, may decide the question."' (alteration in original) (quoting Presley v. City of Benbrook, 4 F.3d 405, 410 (5th Cir. 1993))).

218 See 5 Leonard B. Sand, John S. Siffert, Walter P. Loughlin, Steven A. Reiss \&

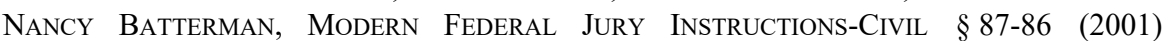
(instructing jury to make determination regarding qualified immunity); MARTIN. A. Schwartz \& George C. Pratt, Section 1983 Litigation Jury Instructions § 17.02.1 (2d ed. 2020) (instructing jury to decide qualified immunity question based on Fifth Circuit approach). But see COMM. ON MODEl JuRy InSTRUCTIONS FOR THE Dist. COURTS OF THE Eighth Circuit, MANuAl of Model Civil Jury Instructions For THE District COURTS OF THE EIGHTH CirCuit $\S 4.42$, at 4-18 (2019), http://www.juryinstructions.ca8 .uscourts.gov/REV4.1CivilJuryInstructions.pdf [https://perma.cc/BS9C-KAAA] ("[T]he issue of good faith immunity is an issue the judge must decide; it is not a jury issue."); COMM. on Pattern Civil Jury Instructions of the Seventh Circuit, Federal Civil Jury InSTRUCTIONS OF THE SEVENTH CiRCUIT $§ 7.18$, at 156 (2009), http://www.ca7.uscourts.gov /Pattern_Jury_Instr/7th_civ_instruc_2009.pdf [https://perma.cc/3R7H-ATCP] (stating Seventh Circuit's view that qualified immunity presents no jury questions and is to be resolved solely by court); FifTH CiRCUIT Dist. JUdGES ASS'N COMM. ON PATTERN JURY Instructions, Pattern Jury Instructions (Civil Cases) § 10.3, at 94 (rev. ed. 2020), www.lb5.uscourts.gov/juryinstructions/Fifth/2020civil.pdf [https://perma.cc/UDM7-NSHR] ("If, after considering the scope of discretion and responsibility generally given to [specify type of officers/officials] in performing their duties and after considering all of the circumstances of this case as they would have reasonably appeared to Defendant [name] at the time of the [specify disputed act], you find that Plaintiff [name] failed to prove that no reasonable [officer/official] could have believed that the [specify disputed act] was lawful, then Defendant [name] is entitled to qualified immunity, and your verdict must be for Defendant [name] on those claims." (alterations in original)); NINTH CIRCUIT JURY Instructions Comm., Manual of Model Civil Jury Instructions $§ 9.34 \mathrm{cmt}$. (2020) ("The committee has not formulated any instructions concerning qualified immunity because most issues of qualified immunity are resolved before trial...."); SCHWARTZ \& PRATT, supra, $\S 17.02 .1$ (stating that giving qualified immunity instruction to jury is a minority view among jurisdictions); THIRD CIRCUIT CIVIL INSTRUCTIONS, supra note 208, § 4.7.2, at 63 ("If there are no disputes concerning the relevant historical facts, then qualified immunity presents a question of law to be resolved by the court."). Additional circuits do not have civil pattern jury instructions. 
immunity separate from the question of whether the constitutional rights of the defendant were violated. As Judge Jon. O. Newman has commented:

To most jurors hearing a jury instruction on the defense of qualified immunity, it simply sounds as if the officer should not be found liable if he [subjectively] thought he was behaving lawfully, and many jurors will give him the benefit of the doubt on that issue, even if they think his conduct was improper. ${ }^{219}$

That question has real importance where a municipality may still be held liable for a constitutional violation even if the individual officers are found immune. ${ }^{220}$ The Fifth Circuit qualified immunity instruction raises still additional problems because it suggests to jurors that the officers' subjective belief as to the reasonableness of their actions might be relevant, despite the fact that the Supreme Court has rejected a subjective qualified immunity test. 221

Some courts state that the jury may have a limited role in informing the judge's decision regarding qualified immunity. In the Eighth Circuit, "special interrogatories related to [the qualified immunity] defense [are] not improper per se," 222 but they must be carefully crafted so that "[t]he fact-finder's role is limited to determining whether the underlying facts are as the plaintiff has alleged or proved." 223 I, along with other commentators, view that as the preferable approach, although still more preferable would be to not call on jurors to reach any decision regarding qualified immunity. ${ }^{224}$ The remedial rules the

${ }^{219}$ Federal Response to Police Misconduct: Hearing Before the Subcomm. on Civil \& Constitutional Rights of the H. Comm. on the Judiciary, 102d Cong. 34 (1992) (statement of J. Jon O. Newman, U.S. Court of Appeals for the Second Circuit).

${ }^{220}$ Monell v. Dep't of Soc. Servs., 436 U.S. 658, 690-91 (1978) (“"L]ocal governments, like every other $\S 1983$ 'person,' by the very terms of the statute, may be sued for constitutional deprivations visited pursuant to governmental 'custom' ....').

221 See, e.g., Harlow v. Fitzgerald, 457 U.S. 800, 817-18 (1982) (rejecting subjective test in favor of "objective reasonableness" test, explaining that "[j]udicial inquiry into subjective motivation therefore may entail broad-ranging discovery and the deposing of numerous persons, including an official's professional colleagues").

${ }^{222}$ Lampkins v. Thompson, 337 F.3d 1009, 1014 (8th Cir. 2003).

${ }^{223}$ McIntosh v. Weinberger, 810 F.2d 1411, 1431 n.8 (8th Cir. 1987), vacated and remanded sub nom. Turner v. McIntosh, 487 U.S. 1212 (1988); see also Johnson v. Breeden, 280 F.3d 1308, 1318 (11th Cir. 2002) ("It is important to recognize, however, that a defendant is entitled to have any evidentiary disputes upon which the qualified immunity defense turns decided by the jury so that the court can apply the jury's factual determinations to the law and enter a post-trial decision on the defense.”); Peterson v. City of Plymouth, 60 F.3d 469, 476 (8th Cir. 1995) (granting new trial where district court submitted qualified immunity issue to jury and stating "the role of the jury in the new trial should be limited to determining what the officers knew at the time of the arrest. In light of the jury's findings, the court should then determine the legal questions of probable cause and qualified immunity"); Warren v. Dwyer, 906 F.2d 70, 76 (2d Cir. 1990) (holding that jury should decide any unresolved factual dispute, but " $[t]$ he ultimate legal determination whether, on the facts found, a reasonable police officer should have known he acted unlawfully is a question of law better left for the court to decide").

${ }^{224}$ See Karen Blum, Qualified Immunity in the Fourth Amendment: A Practical 
Supreme Court crafted to guide judicial management during motions to dismiss or motions for summary judgment do not and should not provide rules of decision for adjudicating constitutional rights in $\S 1983$ trials for damages.

\section{Treating Floors as Ceilings}

This Article examines the use of constitutional doctrine in procedural or institutional contexts which it was not intended to regulate. In other words, it examines the transformation of constitutional doctrine intended to provide a floor or bare minimum protection into a ceiling beyond which actors do not provide further protection. This problem is particularly troubling when it results in underenforcement of rights by citing to federal constitutional law.

In some contexts, however, what is a floor and what is a ceiling may be contested and may be unclear from Supreme Court decisions. In the equal protection context, the Court has developed a series of holdings forbidding not only certain forms of race discrimination and classifications but also some types of affirmative action. ${ }^{225}$ As a result, when states have enacted bars on affirmative action in higher education (which nine states have done), ${ }^{226}$ there is a real question as to whether they have raised the constitutional floor, lowered the constitutional ceiling, or acted consistently with or contrary to Supreme Court guidance. ${ }^{227}$ It is challenging to say whether such statutes are misplaced uses of

Application of $\S 1983$ as It Applies to Fourth Amendment Excessive Force Cases, 21 Touro L. REV. 571, 595-96 (2005) (agreeing with Eighth Circuit opinion that court may "rely upon the factual findings of the jury to decide the issue of qualified immunity," but jury may not decide question of qualified immunity itself); Catherine T. Struve, Constitutional Decision Rules for Juries, 37 Colum. Hum. RTS. L. REV. 659, 681-82 (2006) (“Admittedly, in order to dispose of the case without trial, the judge must ask whether any reasonable jury could find for the non-moving party. But this does not mean that the decision rule employed by the judge must be worded in the same way as the decision rule for a jury." (footnote omitted)).

225 See, e.g., Gratz v. Bollinger, 539 U.S. 244, 270 (2003) (holding that strict scrutiny requires more careful approach than point-based affirmative action system); Grutter v. Bollinger, 539 U.S. 306, 332-33 (2003) (finding that affirmative action program that considered race of applicant among many other variables satisfied strict scrutiny); City of Richmond v. J.A. Croson Co., 488 U.S. 469, 493 (1989) (holding that strict scrutiny applies to uses of affirmative action in employment); Regents of the Univ. of Cal. v. Bakke, 438 U.S. 265, 289-90 (1978) (plurality opinion) (holding that use of quotas in higher education violates Equal Protection Clause).

226 Dominique J. Baker, Why Might States Ban Affirmative Action?, Brookings (Apr. 12, 2019), https://www.brookings.edu/blog/brown-center-chalkboard/2019/04/12/why-mightstates-ban-affirmative-action/ [https://perma.cc/NA3V-LDX8] (presenting research on nine states that have ever banned affirmative action, of which one state's ban was ultimately reversed).

227 See Schuette v. Coal. to Defend Affirmative Action, Integration \& Immigrant Rights \& Fight for Equal. by Any Means Necessary (BAMN), 572 U.S. 291, 298-315 (2014) (assessing whether amendment to the Constitution of Michigan prohibiting state and other governmental entities in Michigan from granting race-based preferences in wide range of actions and decisions was constitutional under the Equal Protection Clause of the Fourteenth Amendment). 
constitutional rulings from the Court, which has restricted some, but certainly not all, uses of affirmative action. If the Court had clearly stated that some affirmative action was protected - or even required - to remedy historical discrimination, then those statutes would raise constitutional questions. It is not clear whether they are building on constitutional norms (forbidding some uses of affirmative action) or undermining constitutional norms (remedying current and historical discrimination). The lack of clarity is due to the contested state of the Supreme Court's doctrine; in its ruling in Schuette v. Coalition to Defend Affirmative Action, ${ }^{228}$ the Court held that such statutes are constitutional expressions of voter preferences. ${ }^{229}$

Where it is clear that constitutional rights do not apply in a setting, and yet they are applied in a manner that reduces protection, it might very well be the case that state and local actors will continue to underenforce without reference to the federal model. The account here is not causal. However, federal constitutional law may provide added justification for underenforcement, and I argue here that is likely why it is being relied upon in these contexts. One could also imagine that state and local actors might borrow federal standards to justify enforcement that is broader and extends beyond the constitutional floor. They might similarly be citing to the Constitution to justify increasing protection without having to fully provide the justification for doing so under state law. Doing so may not risk the same underprotection of rights, but it raises similar legitimacy concerns in which a state or locality is not making a deliberate policy and law choice independently.

\section{CONCLUSION}

In a range of important and unrelated areas of constitutional law-and sometimes despite the Supreme Court's cautionary language-constitutional rules have taken hold outside of the administrative and procedural settings that they were primarily designed to regulate. What results is unanticipated and misplaced changes to rules and practice. This Article has described judicial decisions that profess not to alter an area of law but have had that very effect and how such decisions have had the effect of undermining (or augmenting) the very constitutional protections that they sought to create. Rulings by the Court designed to protect or elaborate the underlying constitutional right have done more: they have become part of the instructions given to a jury when weighing evidence in a case, affected rules for admissibility of expert evidence, and governed decisions regarding whether to prosecute police officers, among other things. In doing so, judicial and executive actors have eroded rights by overextending them to the wrong government actors or by using them in unintended procedural or remedial contexts.

The problem of misplaced constitutional law should be addressed far more carefully by judges and other legal actors. The Supreme Court should step in to correct unintentional misuses of constitutional doctrine in lower courts. As

\footnotetext{
228572 U.S. 291 (2014).

${ }^{229}$ Id. at 313-15.
} 
noted, the Court has done so in some contexts, trying to keep certain types of constitutional rulings confined to civil suits for damages, pretrial remedies in criminal cases, or post-conviction relief. That type of border control, however, is selective, perhaps sometimes reflecting the selective attention of the Justices. Further, some of these misplacements have occurred in areas - such as jury instructions and the exercise of prosecutorial discretion - that are not readily challenged in litigation. They have gone unnoticed and often cannot easily be remedied.

One overarching theme of this Article is that government actors should be more explicit and careful when deciding whether a constitutional baseline should inform decision-making. The Court should examine bare citations to constitutional standards to assess whether they are in fact applicable. Lower court judges and executive officials should be careful not to incorporate constitutional tests in ways that serve different purposes from those they were intended to serve, as doing so can underprotect rights or prevent government actors from crafting more protective rules. More clearly addressing the misplaced use of constitutional rights in new procedural and institutional contexts can help to prevent unanticipated augmentation-or worse, the erosion - of constitutional rights. 